\title{
Protective effect of Lactobacillus fermentum CQPC04 on dextran sulfate sodium-induced colitis in mice is associated with modulation of the nuclear factor-KB signaling pathway
}

\author{
Xianrong Zhou, ${ }^{1,2,3,4,5 *}$ Huazhi Liu, ${ }^{6 *}$ Jing Zhang, ${ }^{7}$ Jianfei Mu, ${ }^{1,2,3,4,5}$ Zsolt Zalan, ${ }^{8}$ Ferenc Hegyi, ${ }^{8}$ \\ Krisztina Takács, ${ }^{8}$ Xin Zhao, ${ }^{3,4,5} \dagger$ and Muying $\mathrm{Du}^{1,2} \dagger$ \\ ${ }^{1}$ College of Food Science, Southwest University, Chongqing 400715, China \\ ${ }^{2}$ Chinese-Hungarian Cooperative Research Centre for Food Science, Southwest University, Chongqing 400715, China \\ ${ }^{3}$ Chongqing Collaborative Innovation Center for Functional Food, Chongqing University of Education, Chongqing 400067, China \\ ${ }^{4}$ Chongqing Engineering Research Center of Functional Food, Chongqing University of Education, Chongqing 400067, China \\ ${ }^{5}$ Chongqing Engineering Laboratory for Research and Development of Functional Food, Chongqing University of Education, Chongqing 400067, \\ China \\ ${ }^{6}$ First Affiliated Hospital of Gannan Medical University, Ganzhou 341000, Jiangxi, China \\ ${ }^{7}$ Environment and Quality Inspection College, Chongqing Chemical Industry Vocational College, Chongqing 401228, China \\ ${ }^{8}$ Food Science Research Institute of National Agricultural Research and Innovation Center, Budapest H-1022, Hungary
}

\section{ABSTRACT}

Colitis severely affects the quality of life of patients, and lactic acid bacteria have been reported to be able to improve or treat colitis. In this study, we selected a strain of Lactobacillus fermentum (CQPC04) with good resistance in vitro to evaluate its effect on improvement in mice with dextran sulfate sodium (DSS)-induced colitis. We analyzed the effects of $L$. fermentum CQPC04 on mice with colitis macroscopically via colon length and histopathology. We also used conventional biochemical and ELISA kits, real-time quantitative PCR (RT-qPCR), and Western blotting to analyze microscopically the effects of $L$. fermentum CQPC04 on related oxidant indices and pro- and anti-inflammatory cytokines in serum and colon tissue of mice. The results indicated that L. fermentum CQPC04 notably increased colon length and ameliorated pathological damage of colon tissue in colitic mice. Serum indices showed that L. fermentum CQPC04 increased the enzyme activity of total superoxide dismutase (T-SOD) and catalase (CAT) and decreased the content of malondialdehyde (MDA) and the activity of myeloperoxidase (MPO). In addition, it inhibited the release of the pro-inflammatory cytokines tumor necrosis factor- $\alpha$ (TNF- $\alpha$ ), IFN- $\gamma$, IL-1 $\beta$, IL-6, and IL-12, and increased the release of the anti-inflammatory cytokine IL-10 in serum. The RT-qPCR experiments confirmed that $L$.

\footnotetext{
Received April 22, 2019.

Accepted July 10, 2019.

*These authors contributed equally to this work.

$\dagger$ Corresponding authors: zhaoxin@cque.edu.cn and muyingdu@swu .edu.cn
}

fermentum CQPC04 downregulated the expression of pro-inflammatory cytokine nuclear factor- $\kappa \mathrm{B}-\mathrm{p} 65$ (NF$\kappa B p 65)$, NF- $\kappa$ B inhibitor- $\alpha$ (I $\kappa$ B- $\alpha)$, TNF- $\alpha$, IFN- $\gamma$, IL-1 $\beta$, IL-6, cyclooxygenase 2 (COX-2), and inducible nitric oxide synthase (iNOS), and upregulated the expression of IL-10 in colon tissue. Western blot analysis indicated that $L$. fermentum CQPC04 significantly reduced expression of NF- $\kappa$ Bp 65 , TNF- $\alpha$, IL-1 $1 \beta$, COX-2, and iNOS in mouse colon tissues, and increased expression of I $\kappa \mathrm{B}-\alpha$ and superoxide dismutase 2 (SOD2). Thus, L. fermentum CQPC04 could effectively alleviate the symptoms of DSS-induced colitis mice and is a potential probiotic for human experiments.

Key words: naturally fermented pickle, Lactobacillus fermentum, dextran sulfate sodium (DSS), colitis, inflammatory factor

\section{INTRODUCTION}

The production of Chinese pickles has a history spanning thousands of years. The perennial low-temperature fermentation environment results in the emergence of lactic acid bacteria (LAB) as the dominant microorganisms in the fermentation process (Ragul et al., 2017). Chinese pickles are mainly fermented by Lactobacillus fermentum, Lactobacillus plantarum, Lactobacillus pentosus, Lactobacillus sake, Lactobacillus brevis, and Lactobacillus casei, among others (Huang et al., 2009; Qian et al., 2018). Many studies have isolated and identified LAB from natural fermented pickles. In addition to common $\mathrm{LAB}$, some rare $\mathrm{LAB}$ have been isolated from pickles. Miyamoto et al. (2005) isolated a new strain of Lactobacillus harbinensis sp. nov. from traditional fermented vegetables ("suan cai") in Harbin, northeastern China. Other studies have used PCR- 
denaturing gradient gel electrophoresis technology to identify strains that cannot be isolated and identified by traditional methods; such strains include Lactobacillus pentosus, Lactobacillus faecalis, and Lactobacillus salivarius. With the ongoing development of the pickle industry, traditional, naturally fermented pickles have gradually been replaced by industrial pickles. However, deep exploration of LAB with probiotic potential in traditional, naturally fermented pickles not only enriches the LAB strain library, but also provides available strains for the in-depth study of probiotics, which are beneficial for human physiological functions.

Lactic acid bacteria play an important role in human physiology. They maintain the micro-ecological balance in many parts of the body, including the mouth, gastrointestinal tract, and vagina. Li et al. (2014) studied the cholesterol-lowering effect of Lactobacillus plantarum NCU116 on lipid metabolism in rats fed a high-fat diet. The results showed that Lactobacillus plantarum NCU116 can regulate lipid metabolism and reduce serum cholesterol in obese rats. Suo et al. (2016) found that Lactobacillus fermentum Suo has a significant beneficial effect on mice with $\mathrm{HCl}$ - or ethanol-induced gastric injury. Zhao et al. (2015) found that Lactobacillus casei Qian has a favorable preventive effect on mice with activated carbon-induced constipation via serum index, mRNA expression, and protein expression of related genes. Some studies have reported that LAB have a variety of physiological functions, such as regulating intestinal flora balance and enhancing immunity, as well as anticancer, antitumor, and antiallergy properties (Lin and Zhang, 2017; Thomas et al., 2017; Barko et al., 2018). Because LAB have many physiological effects in the human body, the study of LAB has become a research hotspot in the fields of food and medicine in recent years.

Ulcerative colitis (UC) is a chronic type of inflammatory bowel disease. However, its pathogenesis is still not completely understood. It is believed that the factors affecting its pathogenesis primarily include immune factors, genetic factors, environmental factors, and intestinal microbial factors (Storr, 2013; Bohr et al., 2014). The clinical manifestations of UC include abdominal pain, diarrhea, intermittent blood in the stool, vomiting, and weight loss, accompanied by pathological changes to areas such as the eyes, skin, mucous membranes, hepatobiliary system, and joints, which seriously affect the quality of life of patients (Chen et al., 2017). The intestinal pathological changes in the UC model induced by dextran sulfate sodium (DSS) are closest to human UC. At present, the concentration of DSS used to model colitis is 3 to $5 \%$, and the molecular weight of DSS commonly used in the colitis model is 36 to $50 \mathrm{kDa}$. This modeling method can induce acute as well as chronic colitis. The mechanism of DSS-induced colitis may be related to its direct toxicity to the intestinal epithelial cells of the basal crypt; it may simultaneously affect the integrity of the mucosal barrier, inhibit epithelial cell proliferation, affect DNA synthesis, destroy the intestinal barrier membrane, and cause intestinal flora imbalance and macrophage dysfunction (Chassaing et al., 2014; Kim et al., 2018). The current treatment of colitis depends primarily on drugs such as mesalazine, sulfasalazine, budesonide, and ciprofloxacin. Drug treatment is often accompanied by a variety of side effects. In recent years, intestinal probiotic preparations (e.g., bifidobacteria, LAB preparations) have attracted much attention in the treatment of colitis; they do not cause side effects and effectively relieve the inflammation symptoms of colitis.

In this study, we isolated and purified a strain of LAB from naturally fermented pickle in Chongqing, China. The 16S rDNA sequence analysis indicated that it was a strain of Lactobacillus fermentum, which we named Lactobacillus fermentum CQPC04. In previous experiments, we evaluated the effects of 11 strains of LAB isolated from pickle on the sensory quality of fermented yogurt. The results showed that the milk curdling effect of L. fermentum CQPC04 was the best. The yogurt fermented by this strain has a rich fermented milk flavor, a fine and smooth mouthfeel, a thick texture, a sweet and sour taste, and the highest sensory score (data not published). On this basis, we wanted to further explore the probiotic function of this strain, provide preliminary experimental support for the application of this strain in yogurt fermentation, and evaluate its use in the development of new functional LAB-fermented dairy products. To this end, we selected this strain to improve intestinal function as an evaluation index, evaluated its effect on DSS-induced colitis model mice, and then evaluated its probiotic effect in the intestine. We evaluated the mitigation effect of this strain on colitis mice by examining colon length, histopathological changes, serum antioxidant index, serum inflammatory cytokine levels, mRNA, and protein expression levels of related genes. Our results provide the theoretical basis and raw materials for an in-depth study of the treatment of colitis by LAB, as well as the development of new LAB preparations.

\section{MATERIALS AND METHODS}

\section{Microorganism Strains}

A new strain of LAB was isolated from naturally fermented pickles in Chongqing and preserved at the 
China General Microbiological Culture Collection Center (CGMCC, Beijing, China) under CGMCC accession number 14493; it was named Lactobacillus fermentum CQPC04.

\section{Animals}

Seven-week-old female ICR mice $(\mathrm{n}=50)$ were purchased from the Experimental Animal Center of Chongqing Medical University [Chongqing, China; SCXK (YU) 2017-0001]. Mice were maintained in a temperature- and humidity-controlled facility (25 \pm $2^{\circ} \mathrm{C}, 50 \pm 5 \%$ relative humidity) with a 12 -h light/ dark cycle and unrestricted access to a diet of standard mouse chow and water.

\section{Tolerance of LAB to Simulated Gastric Juice ( $p H$ 3.0)}

The simulated gastric juice consisted of $0.2 \% \mathrm{NaCl}$ and $0.35 \%$ pepsin (Beijing Solarbio Biotechnology Co. Ltd., Beijing, China). The $\mathrm{pH}$ was adjust to 3.0 using 1 $\mathrm{mol} / \mathrm{L} \mathrm{HCl}$, and the gastric juice was then filtered with a filter $[0.22 \mu \mathrm{m}$, polyethersulfone (PES) membrane, Tullagreen, Carrigtwohill, Ireland]. Five milliliters of medium containing cultured bacteria was placed in a 10-mL sterile centrifuge tube and centrifuged at 900 $\times g$ at room temperature for $10 \mathrm{~min}$. The supernatant was decanted and the bacteria were collected and then mixed with $5 \mathrm{~mL}$ of physiological saline to reconstitute the bacterial suspension. One milliliter of the bacterial suspension was added to $9 \mathrm{~mL}$ of simulated gastric juice, and then $1 \mathrm{~mL}$ was removed from the mixture and stored for later analysis (0-h time point). The remaining $9 \mathrm{~mL}$ of liquid was incubated in a temperaturecontrolled water bath $\left(37^{\circ} \mathrm{C}\right.$, rotated at $\left.150 \mathrm{rpm}\right)$ for 3 h. A series of 10-fold dilutions was made from samples taken at the 0 - $\mathrm{h}$ and 3 - $\mathrm{h}$ time points, and viable counts were made using the plate count method. The cells were incubated on de Man, Rogosa, and Sharpe (MRS) solid medium at $37^{\circ} \mathrm{C}$ for $48 \mathrm{~h}$, after which the colony-forming units were counted and the survival rate (SR) was calculated using the following formula: SR $(\%)=\left(\mathrm{N}_{3} / \mathrm{N}_{0}\right) \times 100$, in which SR represents the survival rate of $L$. fermentum CQPC04, and $\mathrm{N}_{3}$ and $\mathrm{N}_{0}$ represent the number of viable cells $(\mathrm{cfu} / \mathrm{mL})$ at $3 \mathrm{~h}$ and $0 \mathrm{~h}$, respectively (Li et al., 2018a).

\section{Growth Efficiency of LAB in $0.3 \%$ Bile Salts}

One hundred microliters of bacterial culture was added to $5 \mathrm{~mL}$ of MRS-thio (MRS with $0.2 \%$ of sodium thioglycolate) broth that contained either $0.3 \%$ ox gall or no ox gall (control). After incubation at $37^{\circ} \mathrm{C}$ for 24 $\mathrm{h}$, the optical density (OD) value of each culture was measured, and the growth efficiency of the bacteria in the presence of ox gall was calculated by comparison with that of the control. The formula is as follows ( $\mathrm{Li}$ et al., 2018a): Growth efficiency $(\%)=\left(\mathrm{A} / \mathrm{A}_{0}\right) / 100$, in which $\mathrm{A}$ is the OD of bacterial cell with $0.3 \%$ (wt/vol) ox gall, and $\mathrm{A}_{0}$ is the OD of bacterial cell without ox gall.

\section{Animals and Treatment}

To investigate the preventive effects of $L$. fermentum CQPC04 against colitis induced by DSS, 50 male mice (6 wk old) were divided into 5 groups $(\mathrm{n}=10$ mice per group) after a 7 -d adaptation period. The specific treatment was as follows (Figure 1): (1) The control group received a standard chow and drinking water throughout the experiment; (2) the DSS group received a standard chow and drinking water in wk 1,2, 4 and 5 , but in wk 3, the mice were given 5\% DSS (molecular mass, 36-50 kDa; MP Biomedicals, Santa Ana, CA) water instead of drinking water; (3) LF-L+DSS and LF-H+DSS groups received a standard chow and drinking water in wk 1,2, 4 and 5, but in wk 3, they were given $5 \%$ DSS water instead of drinking water. They also received a daily dose of $1.5 \times 10^{9} \mathrm{cfu} / \mathrm{kg}$ (low dose) or $5.0 \times 10^{10} \mathrm{cfu} / \mathrm{kg}$ (high dose) of L. fermentum CQPC04, respectively, during the experiment; (4) the SASP+DSS group received a standard chow and drinking water in wk 1, 2, 4 and 5, but in wk 3, they were given $5 \%$ DSS water instead of drinking water. In addition, beginning in wk 3, they were given a daily dose of $500 \mathrm{mg} / \mathrm{kg}$ salicylazosulfapyridine (Shandong Huimeng Biotech Co., Ltd., Shandong, China), a common drug for the treatment of colitis. The control group and the DSS group received a daily dose of $0.01 \mathrm{~mL} / \mathrm{g}$ of saline $(0.9 \%)$ by oral gavage throughout the experiment. All experiments were approved by the Animal Ethics Committee of Chongqing Medical University (Chongqing, China).

\section{Sample Collection}

After $5 \mathrm{wk}$, the mice were killed by cervical dislocation. The entirety of the blood was collected through the inferior vena cava, blood was centrifuged at $900 \times$ $g$ at $4^{\circ} \mathrm{C}$ for $10 \mathrm{~min}$, and serum was removed and stored in a $-80^{\circ} \mathrm{C}$ ultra-low-temperature refrigerator (Thermo Fisher Scientific Co. Ltd., Shanghai, China) for later use. After blood collection, the mice were dissected and colons removed. The length of each colon was measured, approximately $0.5 \mathrm{~cm}$ of colon tissue was cut and fixed in a $10 \%$ formalin solution, and the remaining colon tissue was preserved in a $-80^{\circ} \mathrm{C}$ refrigerator for later use. 


\section{Histological Examination}

The colon tissue was stained with hematoxylin and eosin. The entire staining process included fixation, embedding, sectioning, tableting, dewaxing, and staining. Finally, the sections were fixed in neutral gum. The pathological morphology of colon tissue was observed using an upright microscope (Olympus Scientific Instruments Co. Ltd., Guangdong, China).

\section{Determination of Relative Oxidation Index and Myeloperoxidase Activity in Serum}

The activity of total superoxide dismutase (T-SOD; kit number A007-1-1) and catalase (CAT; A003-12) enzyme activity and content of malondialdehyde (MDA; A001-1-2) content in serum were determined according to the instructions of conventional biochemical kits (NanJing JianCheng Bioengineering Institute, Nanjing, China). The activity of myeloperoxidase (MPO; A044) enzyme in the colons of mice was determined according to the instructions of the kit (NanJing JianCheng Bioengineering Institute).

\section{Cytokine Levels in Serum}

The serum levels of cytokines tumor necrosis factor (TNF)- $\alpha$, IFN- $\gamma$, IL-1 $\beta$, IL-6, IL-10, and IL-12 in colitic mice were measured according to ELISA kit instructions (Beijing Chenglin Biotechnology Co. Ltd., Beijing, China).

\section{Real-Time Quantitative PCR Assay}

Total RNA in colon tissue was extracted by using the Trizol reagent (Thermo Fisher Scientific Inc., Waltham, $\mathrm{MA}$ ), and the RNA was reverse-transcribed into cDNA using a cDNA kit (Thermo Fisher Scientific Inc.). Next, the cDNA was quantified by a microspectrophotometer (Hangzhou Aosheng Instrument Co. Ltd., Hangzhou, China) and amplified by a real-time PCR instrument (Thermo Fisher Scientific Inc.). The amplification conditions were as follows: $95^{\circ} \mathrm{C}$ for $15 \mathrm{~s}, 55^{\circ} \mathrm{C}$ for $30 \mathrm{~s}$, and $72^{\circ} \mathrm{C}$ for $35 \mathrm{~s}$, and the reaction was carried out for 40 cycles. Finally, the relative expression of each gene was calculated by $2^{-\Delta \Delta \mathrm{CT}}$ method, where $\mathrm{CT}$ is the cycle threshold, for which GAPDH was used as an internal reference gene (Wang et al., 2016a). The primer sequences used in this study are provided in Table 1.

\section{Western Blot Assay}

Total protein in the colon tissue was extracted by using RIPA tissue lysate (Thermo Fisher Scientific Inc.), and protein concentration was determined using a bicinchoninic acid (BCA) protein quantification kit (Beijing Solarbio Science \& Technology Co. Ltd., Beijing, China). Gel preparation was carried out according to the instructions of the SDS-PAGE gel kit (Thermo Fisher Scientific Inc.). Fifty micrograms of protein solution was combined with a gel (10\%) for electrophoresis, and the protein on the gel was then transferred to polyvinylidene fluoride (PVDF) membrane (Millipore, Billerica, MA). The protein-containing PVDF membrane was blocked with $5 \%$ skim milk and incubated for $1 \mathrm{~h}$ $\left(25^{\circ} \mathrm{C}\right.$, shaken at $75 \mathrm{rpm}$; incubator shaker, Shidukai Instrument Equipment Co. Ltd., Shanghai, China), and the membrane was incubated for $2 \mathrm{~h}\left(37^{\circ} \mathrm{C}, 75 \mathrm{rpm}\right)$ in the primary antibody solution and for $1 \mathrm{~h}\left(30^{\circ} \mathrm{C}, 80\right.$ $\mathrm{rpm}$ ) in the secondary antibody solution, in which the type and the dilution ratio of primary antibodies are as

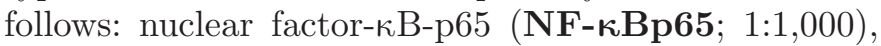

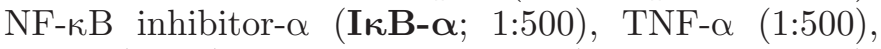

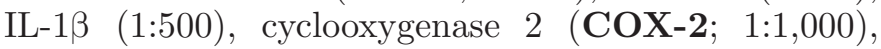
inducible nitric oxide synthase (iNOS; 1:500) and superoxide dismutase 2 (SOD2; 1:500) (Santa Cruz

\begin{tabular}{|c|c|c|c|}
\hline & 2 & 3 & 5 \\
\hline Control & & Saline (oral gavage) & \\
\hline DSS & Saline (oral gavage) & $5 \%$ DSS + saline (oral gavage) & saline (oral gavage) \\
\hline$L F-L+D S S$ & bacterial suspension $\left(1.5 \times 10^{8} \mathrm{cfu} / \mathrm{mL}\right)$ & $5 \%$ DSS + bacterial suspension & bacterial suspension \\
\hline LF-H+DSS & bacterial suspension $\left(5.0 \times 10^{9} \mathrm{cfu} / \mathrm{mL}\right)$ & $5 \%$ DSS + bacterial suspension & bacterial suspension \\
\hline SASP+DSS & SASP $(500 \mathrm{mg} / \mathrm{kg})$ & $5 \%$ DSS + SASP & SASP $(500 \mathrm{mg} / \mathrm{kg})$ \\
\hline
\end{tabular}

Figure 1. Diagram of colitis modeling method. DSS $=$ dextran sulfate sodium, LF $=$ Lactobacillus fermentum CQPC04, LF-L $=$ low dose $\left(1.5 \times 10^{9} \mathrm{cfu} / \mathrm{kg}\right.$ of BW), LF-H $=$ high dose $\left(1.0 \times 10^{10} \mathrm{cfu} / \mathrm{kg}\right.$ of BW $)$, SASP $=$ salicylazosulfapyridine $(500 \mathrm{mg} / \mathrm{kg}$ of BW $)$. 
Table 1. The primer sequences used in this study

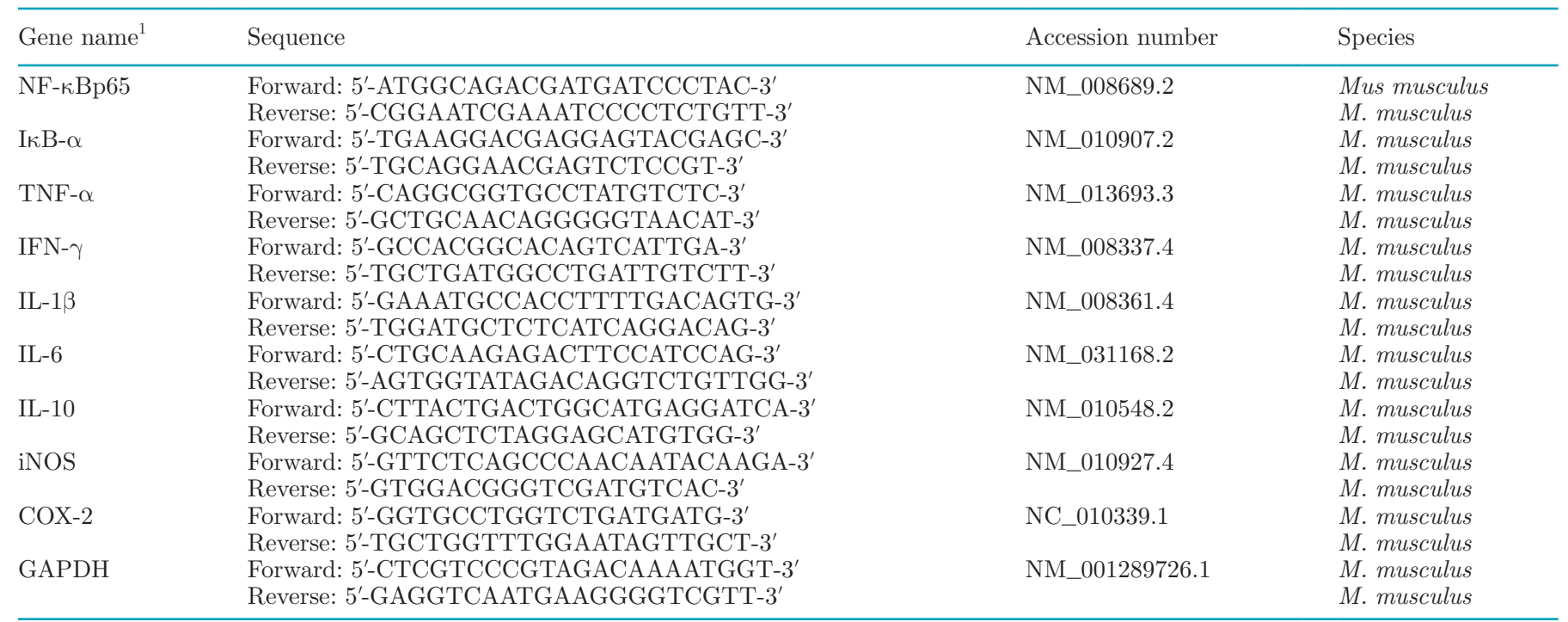

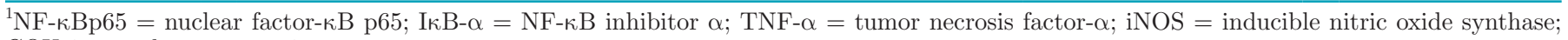
COX-2 = cyclooxygenase 2 .

Biotechnology Inc., Santa Cruz, CA), and the secondary antibody was horseradish peroxidase (HRP)-goat anti-mouse IgG (Thermo Fisher Scientific Inc.) at a dilution ratio of 1:10,000. Finally, the color developing solution was prepared according to the instructions of the hypersensitive chemiluminescence solution (ECL Plus) kit (Beijing Solarbio Science \& Technology Co. Ltd.), and imaging was performed with the Tiangan chemiluminescence imaging system (Tanon Science \& Technology Co. Ltd., Shanghai, China). The images were analyzed by Image $\mathrm{J}$ software (National Institutes of Health, Bethesda, MD), and, finally, the relative expression of the target protein was calculated by using $\beta$-actin as the internal reference protein (Jiang et al., 2013).

\section{Statistical Analysis}

The results were calculated and analyzed using Graph Pad Prism 7.0 software (Graph Pad Software, La Jolla, $\mathrm{CA}$ ) and presented as the mean \pm standard deviation (SD). The comparison of the differences between the data sets was conducted using ANOVA.

\section{RESULTS}

\section{Experimental Strain}

As shown in Figure 2, colonies of the experimental strain on the plate were milky white, round, with a moist, smooth surface. Gram staining demonstrated that the experimental strain was gram-positive and that there was no bud reproduction, both of which are consistent with the morphological characteristics of LAB.

\section{In Vitro Resistance of L. fermentum CQPC04}

The survival rate of $L$. fermentum CQPC04 in artificial gastric juice at $\mathrm{pH} 3.0$ was $84.14 \pm 6.06 \%$, and the growth efficiency in $0.3 \%$ bile salt was (mean $\pm \mathrm{SD}$ ) $66.38 \pm 0.55 \%$. The results indicated that L. fermentum CQPC04 has good in vitro resistance and can be used for subsequent animal experiments.

\section{Colon Length}

To evaluate the effect of colitis on colon length in mice, we measured the colon length of all mice (Figure $3)$. The length of the colon in the control group was $10.10 \pm 0.80 \mathrm{~cm}$, and the length in the DSS group was $7.31 \pm 0.50 \mathrm{~cm}$; there was a significant difference between the 2 groups $(P<0.0001)$. The colon lengths of the LF-L+DSS, LF-H+DSS, and SASP groups were $8.54 \pm 1.05,8.74 \pm 0.88$, and $8.48 \pm 1.03 \mathrm{~cm}$, respectively, and all were significantly longer than that of the DSS group $(P<0.05, P<0.01$, and $P<0.05$, respectively). Additionally, the colon length of mice in the LF-H+DSS group was greater than that of mice in the LF-L+DSS and SASP groups.

\section{Histological Analysis}

The morphology of the colon tissue was observed following hematoxylin and eosin staining, which can be 
seen in Figure 4. In the control group, the mucosal epithelial cells were intact, the crypts were normal, the glands were arranged neatly and orderly, and there were no ulcers. Compared with the control group, the DSS group had severe colonic mucosal erosion, almost all the crypts were destroyed, the goblet cells were drastically reduced, the lamina propria inflammatory cells were infiltrated, the glands were disordered, and severe ulcers were seen. After oral administration of L. fermentum CQPC04 or sulfasalazine, we found, in the LF-L+DSS mice, although there was erosion in the colonic mucosa, the goblet cells were reduced, and a small number of ulcers were observed, but the degree of damage was obviously less than in the model group. Additionally, the colonic mucosa of mice in the LF$\mathrm{H}+\mathrm{DSS}$ and SASP groups did not show obvious erosion, the crypts were relatively intact, the glands were arranged neatly, the goblet cells were more complete, and the morphology of the colon tissue was similar to that of the control group.

\section{MPO Activity in Colon}

When the body is stimulated by infection or inflammation, MPO will increase. In the present study, we found that MPO activity in the colon was highest in mice of the DSS group and significantly higher $(P<$ 0.001 ) that than in the control group (Figure 5). When the colitis mice were administered with different concentrations of L. fermentum CQPC04 intragastrically, $\mathrm{MPO}$ activity in the colon declined; MPO activity in the LF-H+DSS group was significantly lower $(P<$ 0.05) than that in the DSS group and close to that of the SASP group.

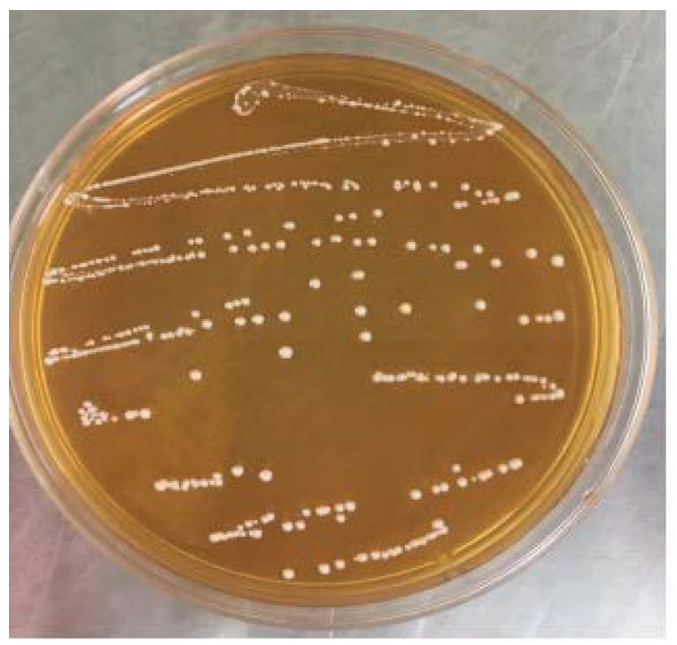

\section{T-SOD, CAT, and MDA Levels in Serum}

As can be seen in Table 2, the activities of CAT and T-SOD in serum were lowest and MDA content highest in the DSS group. Compared with that in the DSS group, activity of CAT was significantly increased in LF-L+DSS $(P<0.01)$, LF-H+DSS $(P<0.001)$, and $\mathrm{SASP}+\mathrm{DSS}(P<0.01)$ mice, activity of T-SOD was significantly increased in LF-H+DSS $(P<0.01)$ and SASP + DSS $(P<0.001)$ mice, and MDA content was significantly decreased in LF-H+DSS mice $(P<0.01)$. The CAT and T-SOD activities and MDA content in the serum of the LF-H+DSS group were the closest to those in the normal group.

\section{Cytokine Levels in Serum}

Pro- and anti-inflammatory cytokines are in a state of dynamic equilibrium under normal conditions. When the body is infected or damaged, the release of proinflammatory cytokines increases, and the release of anti-inflammatory cytokines decreases, thereby aggravating the inflammatory damage to the body. As shown in Figure 6, the levels of TNF- $\alpha$, IFN- $\gamma$, IL-1 $\beta$, IL-12, and IL- 6 in the serum of the control group were the lowest, and the level of IL-10 was the highest, whereas the DSS group exhibited the opposite trend. After the administration of $L$. fermentum CQPC04 to mice, the levels of TNF- $\alpha$, IFN- $\gamma$, IL-1 $\beta$, IL-12, and IL-6 in serum decreased and the level of IL-10 increased. Moreover, the expression results in the LF-H+DSS group were greater than those in the LF-L+DSS group, and administration of $L$. fermentum significantly reduced the release of pro-inflammatory cytokines and increased the release of anti-inflammatory cytokines.

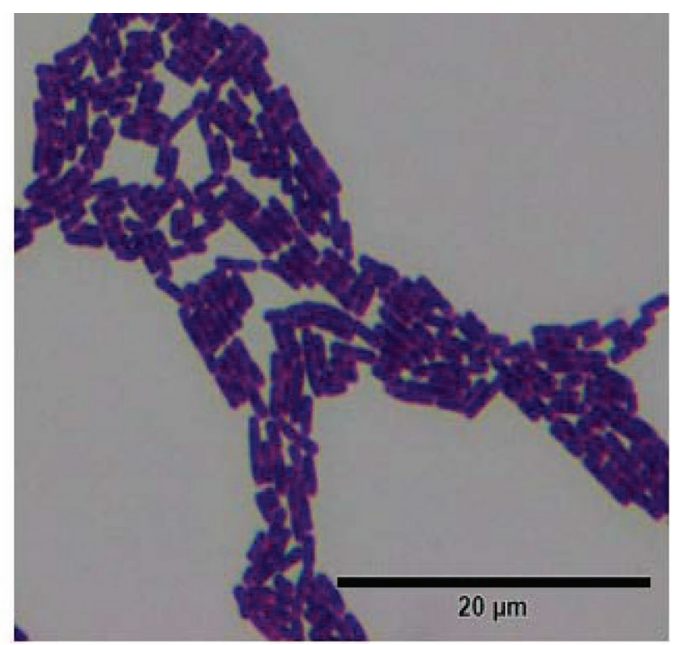

Figure 2. Morphological characteristics of experimental lactic acid bacterium Lactobacillus fermentum CQPC04. 

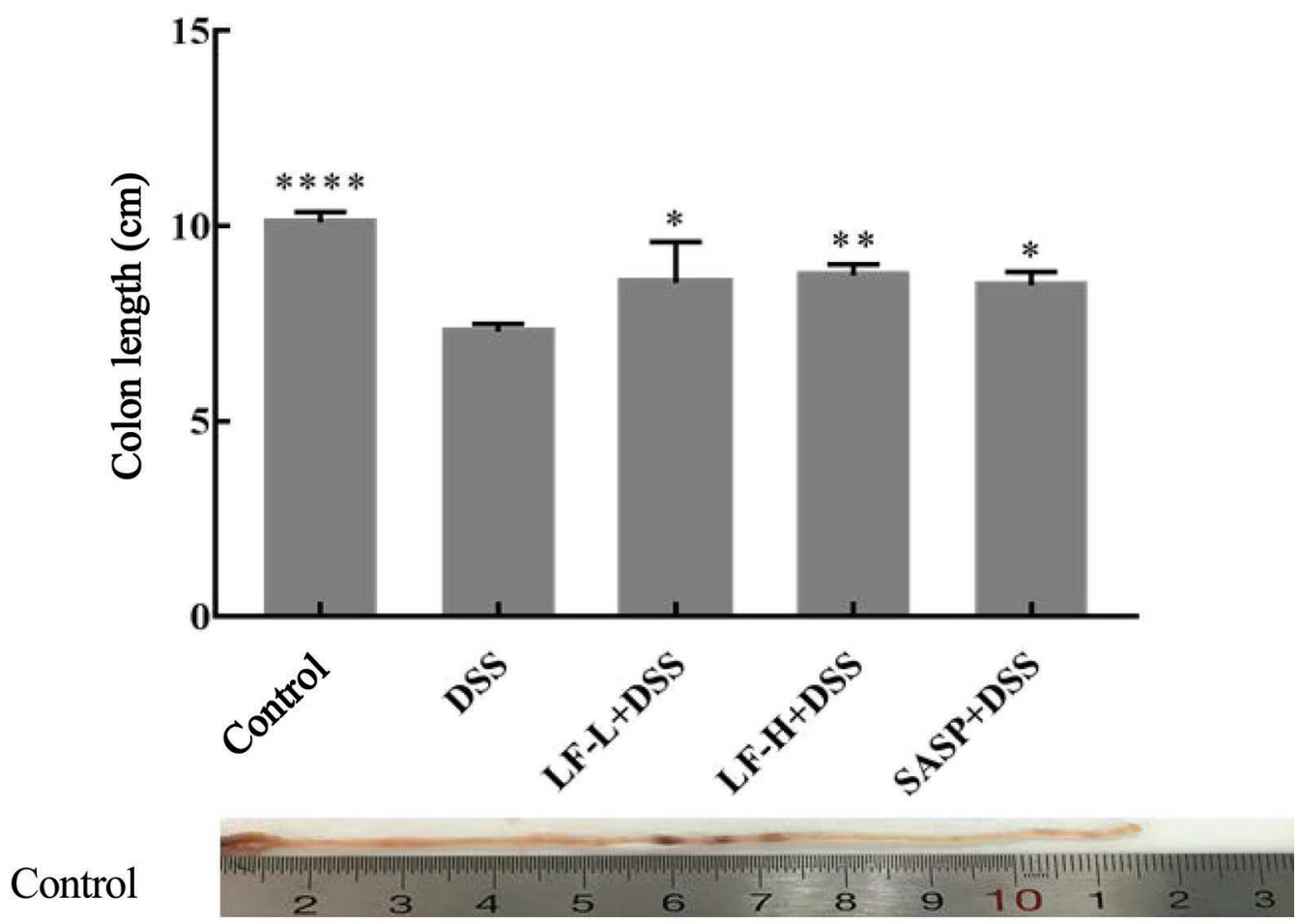

DSS

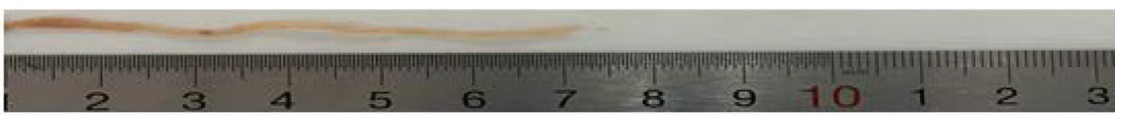

LF-L + DSS

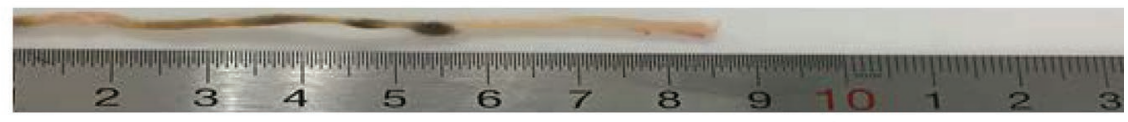

LF-H+DSS

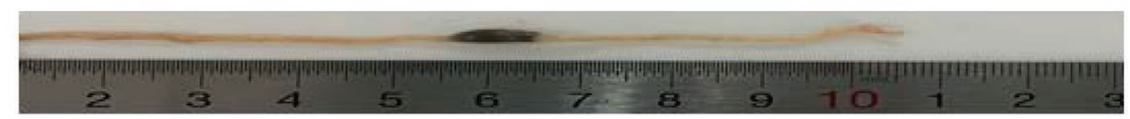

SASP + DSS

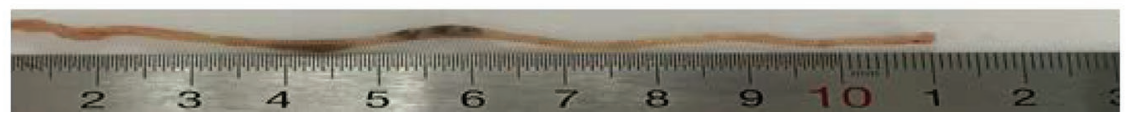

Figure 3. Colon length $(\mathrm{cm})$ of experimental mice. LF-L+DSS = Lactobacillus fermentum CQPC04 $\left(1.5 \times 10^{9} \mathrm{cfu} / \mathrm{kg}\right.$ of BW $)$ plus $5 \%$ dextran sulfate sodium (DSS); LF-H+DSS $=$ L. fermentum CQPC04 $\left(1.0 \times 10^{10} \mathrm{cfu} / \mathrm{kg}\right.$ of BW $)$ plus $5 \%$ DSS; SASP + DSS $=$ salicylazosulfapyridine $(500 \mathrm{mg} / \mathrm{kg}$ of BW $)$ plus $5 \%$ DSS. Data are expressed as mean $\pm \mathrm{SD} ;{ }^{*} P<0.05,{ }^{* *} P<0.01,{ }^{* * * *} P<0.0001$ compared with the DSS group.

\section{mRNA and Protein Expression of NF-KBp65 and IKB- $\alpha$ in Colon}

The NF- $\kappa \mathrm{B}$ signaling pathway plays an important role in the pathogenesis of colitis. Therefore, we measured the mRNA and protein expression of NF- $\kappa$ Bp65 and its inhibitory protein $\mathrm{I} \kappa \mathrm{B}-\alpha$ in mouse colon tissues. As shown in Figure 7, expression of NF- $\kappa$ Bp65 in colon was lowest and expression of $\mathrm{I} \kappa \mathrm{B}-\alpha$ was highest in the control group, whereas the opposite trend was observed in the DSS group. Compared with the DSS group, expression of NF- $\kappa$ Bp65 in colon was decreased in the LF-L+DSS, LF-H+DSS, and SASP+DSS groups and I $\kappa$ B- $\alpha$ expression levels were increased. In addition, the expression level in the LF-H+DSS group was closer to that of the control and SASP groups. At the same time, the expression level of NF- $\kappa \mathrm{Bp} 65$ in the LF-H+DSS group was lower than that of the LF-L+ DSS and the DSS groups, and the expression level of $\mathrm{I} \kappa \mathrm{B}-\alpha$ in the LF-H+DSS group was higher than that of the LF-L+ DSS and the DSS groups.

\section{mRNA and Protein Expression of TNF- $\alpha, I L-1 \beta$,} COX-2, and iNOS

Because TNF- $\alpha$, IL-1 $\beta$, COX-2, and iNOS are inflammation markers associated with activation of the 


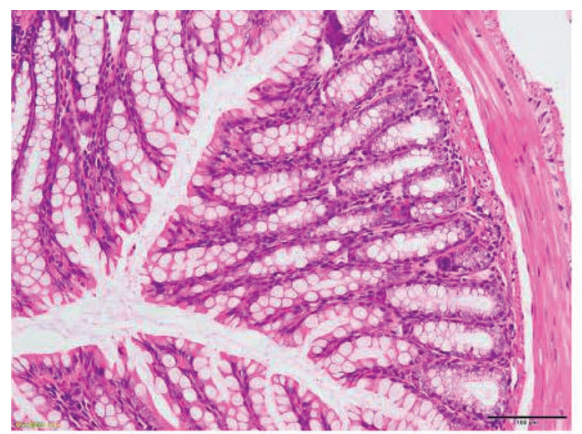

Control

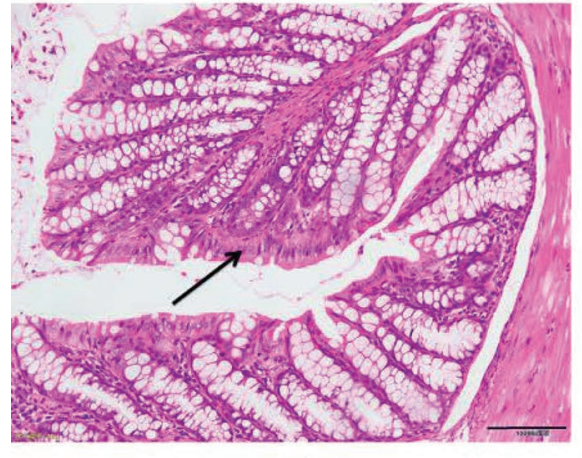

LF-H+DSS

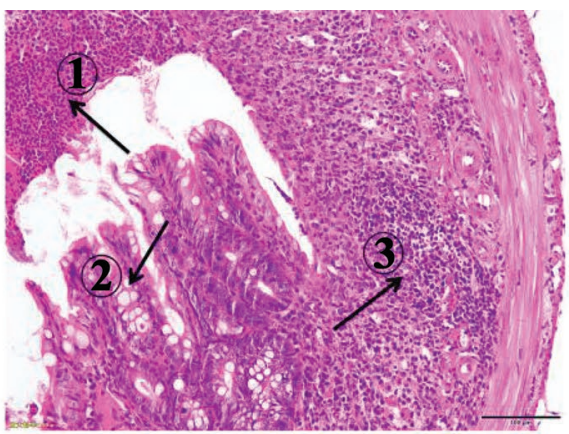

DSS

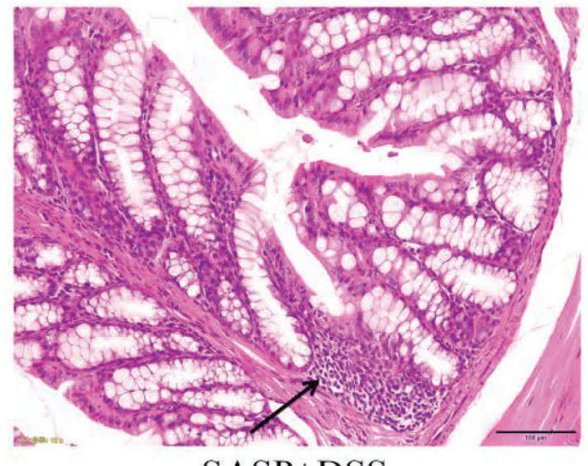

SASP+DSS

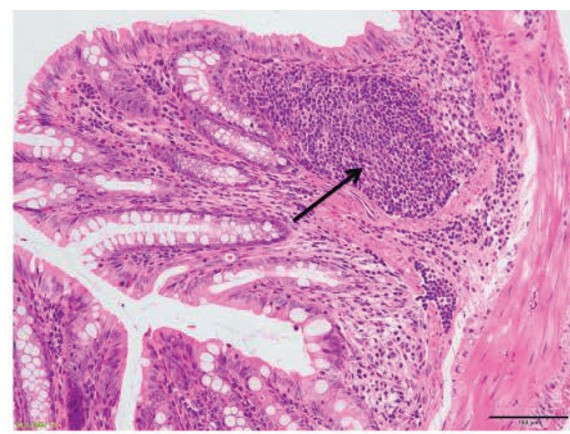

LF-L+DSS

Figure 4. Histopathological observation of colon tissues. Arrow 1 indicates colonic mucosal erosion, arrow 2 indicates a severe reduction in goblet cells, and arrow 3 indicates inflammatory cell infiltration. The arrows in the LF-L+DSS and in the SASP +DSS groups indicate inflammatory infiltration, and the arrow in the LF-H+DSS group indicates colonic mucosal erosion. Control $=$ oral gavage with saline; DSS $=5 \%$ dextran sulfate sodium; LF-L+DSS = Lactobacillus fermentum CQPC04 $\left(1.5 \times 10^{9} \mathrm{cfu} / \mathrm{kg}\right.$ of BW $)$ plus $5 \%$ DSS; LF-H + DSS $=$ L. fermentum CQPC04 $\left(1.0 \times 10^{10} \mathrm{cfu} / \mathrm{kg}\right.$ of BW $)$ plus $5 \%$ DSS; SASP+DSS = salicylazosulfapyridine $(500 \mathrm{mg} / \mathrm{kg}$ of BW $)$ plus $5 \%$ DSS. Magnification $200 \times$. The length of the scale bar in each panel is $100 \mu \mathrm{m}$.

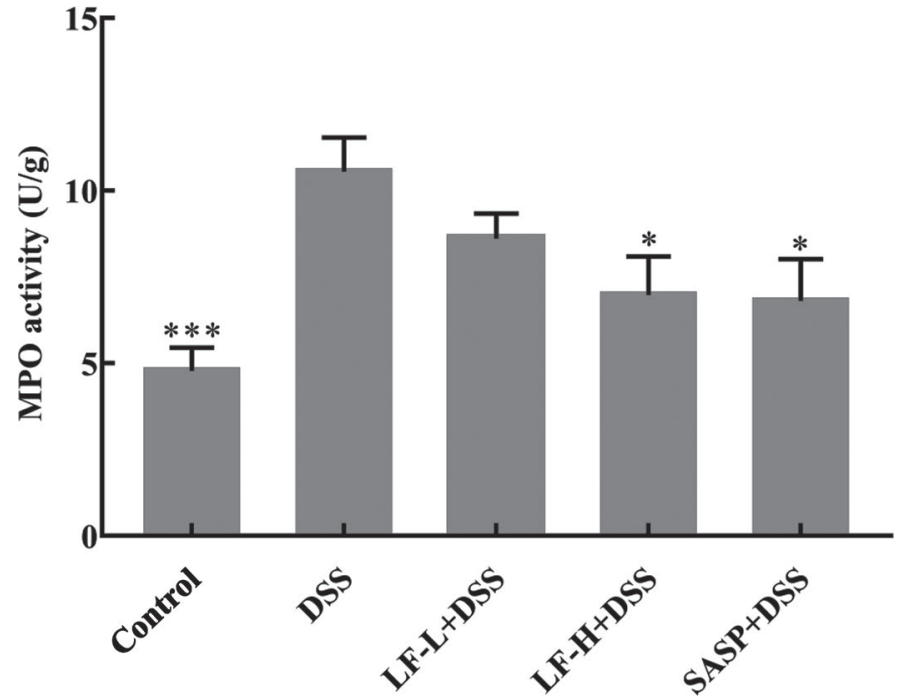

Figure 5. Myeloperoxidase (MPO) activity in colon. Control $=$ oral gavage with saline; DSS $=5 \%$ dextran sulfate sodium; LF-L+DSS $=$ Lactobacillus fermentum CQPC04 $\left(1.5 \times 10^{9} \mathrm{cfu} / \mathrm{kg}\right.$ of BW $)$ plus $5 \%$ DSS; LF-H+DSS $=$ L. fermentum CQPC04 $\left(1.0 \times 10^{10} \mathrm{cfu} / \mathrm{kg}\right.$ of BW $)$ plus $5 \%$ DSS; SASP+DSS = salicylazosulfapyridine $(500 \mathrm{mg} / \mathrm{kg}$ of $\mathrm{BW}$ ) plus $5 \%$ DSS. Data are expressed as mean $\pm \mathrm{SD} ;{ }^{*} P<0.05$ *** $P<0.001$ compared with the DSS group.
NF-кB signaling pathway, we evaluated the effect of $L$. fermentum CQPC04 on colitis by measuring the expression of these markers in colon tissue. Figure 8 shows that expression of TNF- $\alpha$, IL- $1 \beta$, COX-2, and iNOS in colon was highest in the DSS group and lowest in the control group. The mRNA and protein expression of the above markers in the LF-L+DSS, LF-H+DSS, and SASP+DSS groups was higher than in the control group but lower than in the DSS group.

\section{mRNA Expression of IFN- $y$, IL-6, and IL-10}

Figure 9 shows that mRNA and protein expression of IFN- $\gamma$ and IL- 6 were lowest in colon tissues of the control group, and expression of IL-10 was highest. However, the opposite trend was seen in colon tissues of the DSS group. After administration of L. fermentum CQPC04 to mice, expression of IFN- $\gamma$ and IL-6 in mouse colon tissues decreased and expression of IL-10 increased. The above indicators in colon tissues of the LF-H+DSS group were more similar to those of the SASP and control groups. 
Table 2. Activity of total superoxide dismutase (T-SOD) and catalase (CAT) and content of malondialdehyde (MDA) in serum of mice ${ }^{1}$

\begin{tabular}{llll}
\hline Group $^{2}$ & T-SOD $(\mathrm{U} / \mathrm{mL})$ & \multicolumn{1}{c}{ CAT $(\mathrm{U} / \mathrm{mL})$} & MDA $(\mathrm{nmol} / \mathrm{mL})$ \\
\hline Control & $62.11 \pm 3.19^{* * *}$ & $254.52 \pm 31.09^{* * *}$ & $14.76 \pm 5.04$ \\
DSS & $54.92 \pm 6.12$ & $178.60 \pm 33.99$ & $34.33 \pm 6.41$ \\
LF-L+DSS & $58.88 \pm 3.68$ & $208.37 \pm 24.54^{* *}$ & $21.00 \pm 3.25$ \\
LF-H+DSS & $64.93 \pm 2.29^{* *}$ & $246.16 \pm 37.58^{* * *}$ & $18.06 \pm 4.40^{* *}$ \\
SASP+DSS & $57.62 \pm 5.76^{* * *}$ & $249.96 \pm 31.15^{* *}$ & $19.67 \pm 4.92$ \\
\hline
\end{tabular}

${ }^{1}$ Values are the mean $\pm \mathrm{SD}(\mathrm{n}=10 /$ group $)$.

${ }^{2}$ Control $=$ mice fed a standard chow diet plus drinking water; DSS $=$ mice fed the standard chow diet plus drinking water with $5 \%$ dextran sulfate sodium; LF-L+DSS = Lactobacillus fermentum CQPC04 $\left(1.5 \times 10^{9}\right.$ cfu $/ \mathrm{kg}$ of BW) plus $5 \%$ DSS; LF-H+DSS $=$ L. fermentum CQPC04 $\left(1.0 \times 10^{10} \mathrm{cfu} / \mathrm{kg}\right.$ of BW $)$ plus $5 \%$ DSS; SASP + DSS $=$ salicylazosulfapyridine $(500 \mathrm{mg} / \mathrm{kg}$ of BW $)$ plus $5 \%$ DSS.

${ }^{* *} P<0.01,{ }^{* * *} P<0.001$ compared with the DSS group.

\section{Protein Expression of SOD2}

Manganese superoxide dismutase (SOD2) is widely distributed in mitochondria and can effectively remove superoxide anion produced by the body, thereby reducing DNA peroxidation damage. As shown in Figure 10 , protein expression of SOD2 in colon was lowest in the DSS group, being significantly lower $(P<0.05)$ than that of the control group. Expression of SOD2 in the LF-L+DSS, LF-H+DSS, and SASP groups was significantly higher than that of DSS group $(P<0.05$, $P<0.01$, and $P<0.001$, respectively) and was higher in the LF-H+DSS group than in the LF-L+DSS group.

\section{DISCUSSION}

Probiotics are defined as live microorganisms that confer a health benefit to the host when ingested in adequate amounts (Reid and Hammond, 2005). Many clinical studies confirm that probiotics have positive effects on elimination of Helicobacter, inflammatory bowel disease, irritable bowel syndrome, diarrhea and allergic diseases (e.g., atopic dermatitis; Grover et al., 2012; Distrutti et al., 2016; Currò et al., 2017; Ohtsu et al., 2017). Studies have shown that probiotics can be used to treat diseases such as type 2 diabetes, insulin resistance syndrome, obesity, and nonalcoholic fatty liver disease. Lactic acid bacteria are the most prominent probiotics and have received much attention from researchers to prevent various diseases or disorders (Khan and Kang, 2016; Sáez-Lara et al., 2016).

The first condition that must be met for LAB to play a probiotic role in the body is to survive in the intestine; therefore, tolerance to low $\mathrm{pH}$ gastric juice and a complex bile salt environment are 2 important indicators for evaluating the probiotic characteristics of LAB (Kumar et al., 2015). The $\mathrm{pH}$ of the human stomach after feeding is usually around 3.0, and food stays in the stomach for 1 to $3 \mathrm{~h}$ (Pereira and Gibson,
2002). The concentration of bile salts in the human body is between 0.03 and $0.3 \%$. Therefore, the probiotic characteristics of LAB are usually evaluated by using $\mathrm{pH} 3.0$ artificial gastric juice and $0.3 \%$ bile salts. Lee et al. (2011) studied the survival rate of 12 strains of LAB isolated from Korean kimchi after treatment for $1 \mathrm{~h}$ in $\mathrm{pH} 3.0$ artificial gastric juice, and the survival rates of 6 strains of LAB were between 68 and $91 \%$. The ability of a LAB strain to survive in artificial gastric juice is the first characteristic it must exhibit to evaluate its probiotic properties. Some previous studies have shown that LAB that grow well in artificial gastric juice do not necessarily have strong tolerance to bile salts. Zhao et al. (2018) studied the effect of Lactobacillus plantarum YS3 on mice with constipation and although the survival rate of the strain in artificial gastric juice at $\mathrm{pH}$ 3.0 was $72.38 \%$, survival in $0.3 \%$ bile salt was $19.33 \%$. In the current study, L. fermentum CQPC04 exhibited good tolerance to $\mathrm{pH} 3.0$ artificial gastric juice and $0.3 \%$ bile salt and had potential probiotic characteristics. It was therefore deserving of further evaluation to observe its improvement effect on colitis mice.

In general, colon length and colon histopathological changes can be used to macroscopically determine the degree of damage to the colons of colitic mice. The DSS model induces a shorter colon in mice, so measuring colon length is an important indicator to assess the severity of colitis (Naeem et al., 2018). Similarly, histopathological changes in the colon can visually reflect the damage to colon tissue. Irregular morphological changes, lamina propria inflammatory cell infiltration, goblet cell reduction, and colon edema often occur in damaged colon tissue (Aldini et al., 2014). In this study, we confirmed that DSS induction can lead to a decreased colon length and severe changes in the pathological morphology of colon tissue in mice, but that L. fermentum CQPC04 could effectively alleviate colonic shortening and inflammatory lesions of colon tissue. Moreover, colon morphology of mice in the LF- 

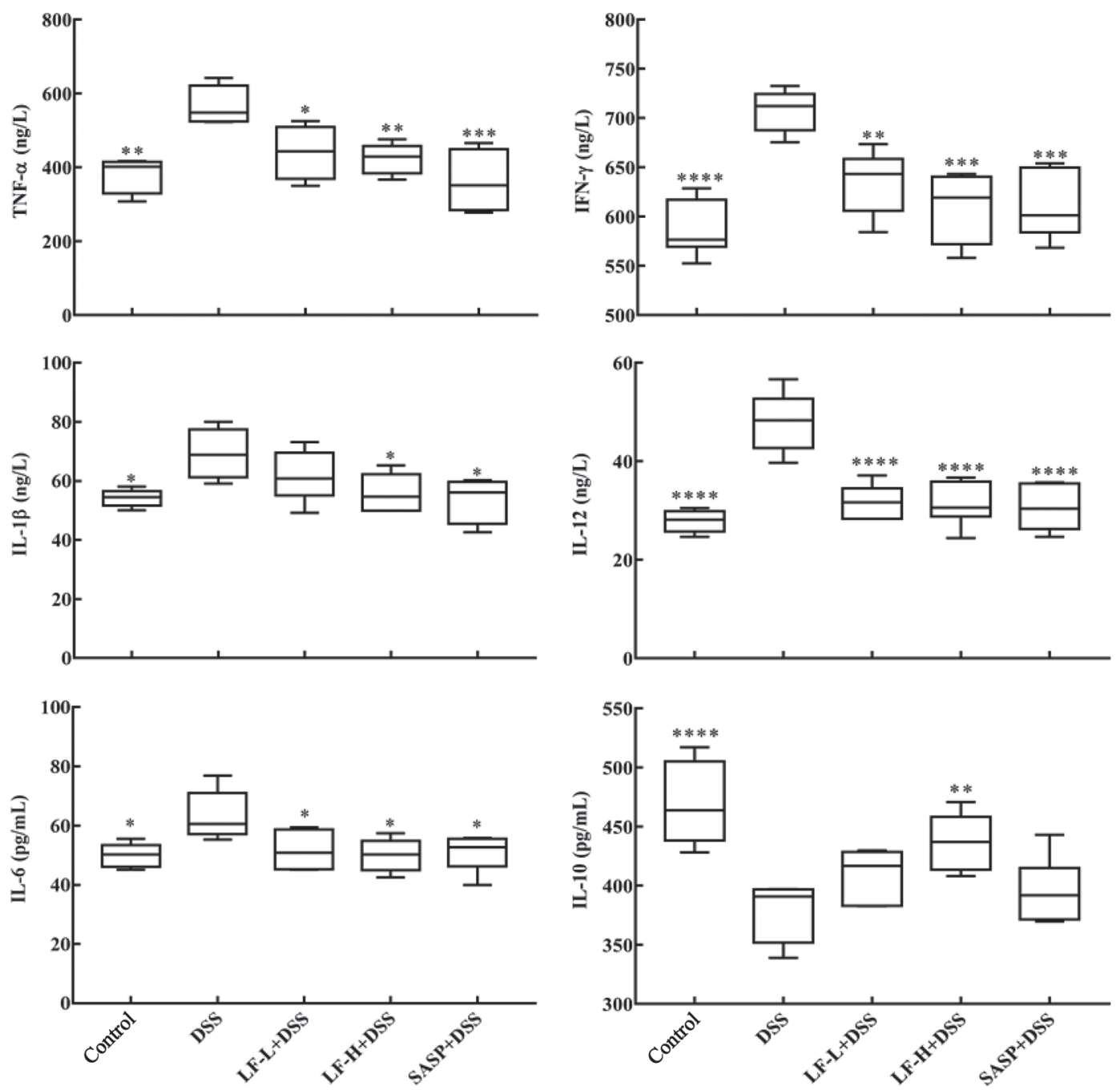

Figure 6. Cytokine levels [tumor necrosis factor (TNF)- $\alpha$, IFN- $\gamma$, IL-1 $\beta$, IL-12, IL-6, IL-10] in serum of mice. Control = oral gavage with saline; DSS $=5 \%$ dextran sulfate sodium; LF-L+DSS = Lactobacillus fermentum CQPC0 $4\left(1.5 \times 10^{9} \mathrm{cfu} / \mathrm{kg}\right.$ of BW $)$ plus $5 \%$ DSS; LF-H+DSS $=$ L. fermentum CQPC0 $4\left(1.0 \times 10^{10} \mathrm{cfu} / \mathrm{kg}\right.$ of BW) plus $5 \%$ DSS; SASP + DSS $=$ salicylazosulfapyridine $(500 \mathrm{mg} / \mathrm{kg}$ of BW $)$ plus $5 \%$ DSS. Data are expressed as mean $\pm \mathrm{SD} ;{ }^{*} P<0.05$, ${ }^{* *} P<0.01,{ }^{* * *} P<0.001,{ }^{* * * *} P<0.0001$ compared with the DSS group. The 5 horizontal lines from the top to the bottom of the boxplots indicate the maximum, the upper quartile, the median, the lower quartile, and the minimum, respectively.

$\mathrm{H}+\mathrm{DSS}$ group was similar to that of both the control and SASP+DSS groups.

Total superoxide dismutase, CAT, MDA, and MPO are all indicators related to body oxidation. Under normal conditions, the generation and elimination of oxygen free radicals are in equilibrium. When inflammation occurs, local hypoxia leads to massive production of oxygen free radicals, leading to apoptosis or damage (Di Meo et al., 2016). The imbalance between production of reactive oxygen species and antioxidant systems is an important factor in the pathogenesis of colitis (Wang et al., 2016b). Superoxide dismutase and CAT are 2 important antioxidant enzymes for scavenging reactive oxygen species in the body's oxidation defense system. Their elevated content means more active oxygen is decomposed and the oxidative damage to the body will be reduced (Xiao et al., 2014). Malondialdehyde is the end product of lipid peroxidation and is often used as a biomarker for oxidative stress. When MDA release increases, it causes cell and tissue damage (Macotpet et al., 2013). Myeloperoxidase is a heme peroxidase present in neutrophils. When the body suffers an infection or inflammation, MPO is released to the outside of the cell and catalyzes the production of hypochlorous acid and tyrosine free radicals that damage human cells and further lead to different degrees of damage to proteins, DNA, and fat; thus, it is considered an effective indicator of inflammation of colon tissue (Casas et al., 2015; Matuszyk et al., 2016). Our study also found that DSS modeling decreased the activity of T-SOD and CAT in 
$\begin{array}{llll}\text { Control DSS } & \text { LF-L+DSS } & \text { LF-H+DSS }\end{array}$

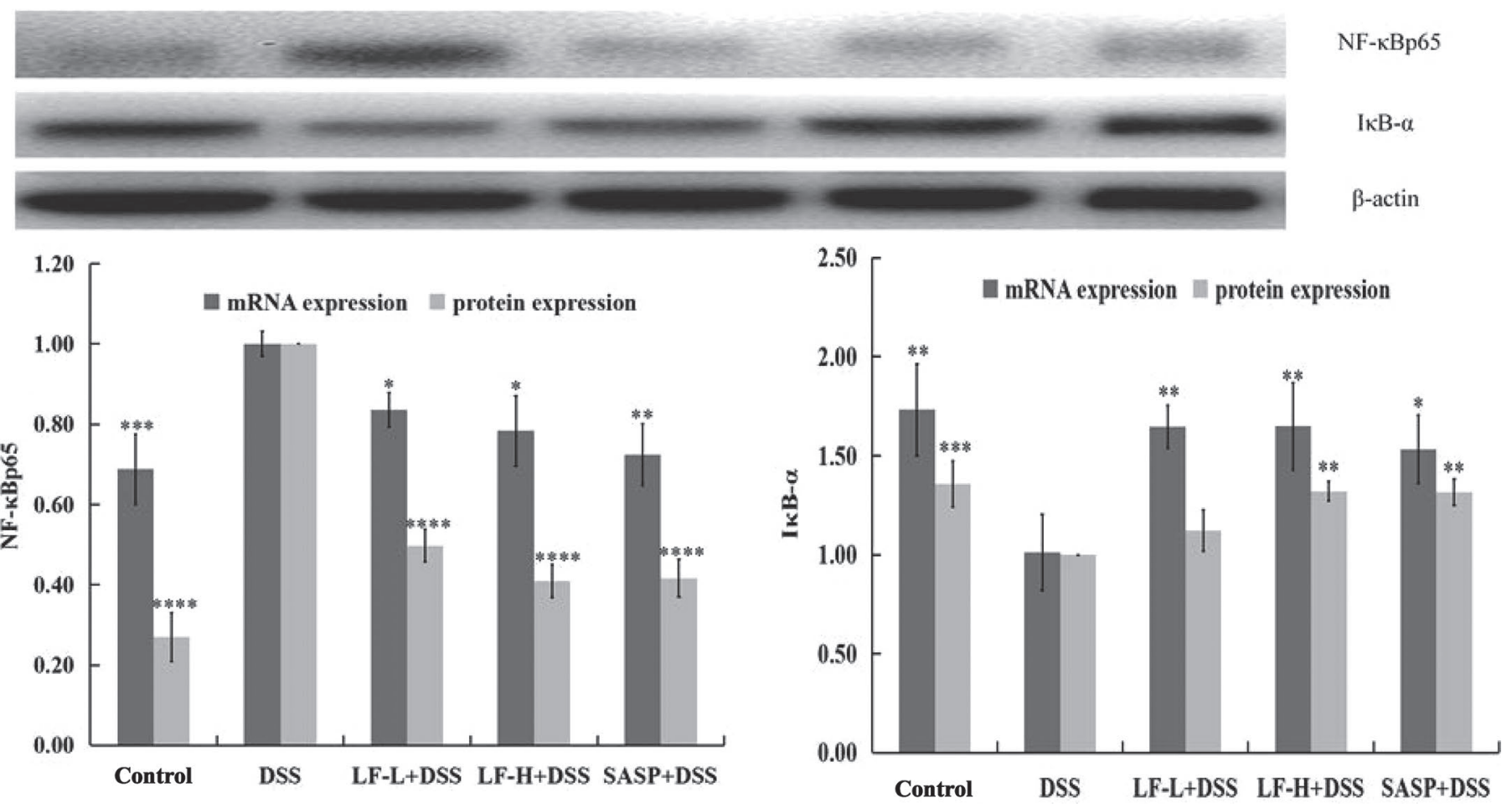

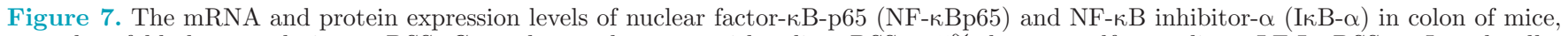
expressed as fold change relative to DSS. Control $=$ oral gavage with saline; DSS $=5 \%$ dextran sulfate sodium; LF-L + DSS $=$ Lactobacillus fermentum CQPC04 $\left(1.5 \times 10^{9} \mathrm{cfu} / \mathrm{kg}\right.$ of BW) plus 5\% DSS; LF-H+DSS = L. fermentum CQPC04 $\left(1.0 \times 10^{10} \mathrm{cfu} / \mathrm{kg}\right.$ of BW $)$ plus $5 \%$ DSS; $\mathrm{SASP}+\mathrm{DSS}=$ salicylazosulfapyridine $\left(500 \mathrm{mg} / \mathrm{kg}\right.$ of BW) plus $5 \%$ DSS. Data are expressed as mean $\pm \mathrm{SD} ;{ }^{*} P<0.05,{ }^{* *} P<0.01,{ }^{* * *} P<$ $0.001, * * * * P<0.0001$ compared with the DSS group.

mouse serum and significantly increased MDA content and MPO activity. After L. fermentum CQPC04 was administered to colitic mice, the activities of T-SOD and CAT in serum were significantly increased, whereas the MDA content and MPO activity were decreased; the high dose of $L$. fermentum CQPC04 effectively improved these indicators. These results indicate that the experimental strain can increase the activity of antioxidant enzymes, reduce lipid peroxidation and free radical production, maintain the balance between reactive oxygen and antioxidant systems, and ultimately reduce oxidative stress damage to colon tissue of colitic mice, which may be related to the antioxidant effects of the LAB themselves.

This study found an interesting phenomenon: $L$. fermentum CQPC04 could inhibit the activation of NF- $\kappa$ Bp65 in colon tissue of colitis mice and the inhibition effect was greater with increasing $L$. fermentum CQPC04 concentration. Nuclear factor- $\kappa \mathrm{B}$ is an important transcription factor in the process of immune response. It normally binds to its inhibitory protein, $\mathrm{I} \kappa \mathrm{B}$, in an inactive state. We found that DSS modeling accelerated the phosphorylation of I $\mathrm{B}$ p protein, which

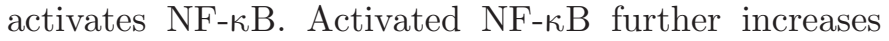
release of pro-inflammatory cytokines and markers, including TNF- $\alpha$, IFN- $\gamma$, IL-1 $\beta$, IL-6, IL-12, COX-2, and iNOS. Many studies have shown that the NF- $\kappa$ B signaling pathway is closely related to the inflammatory response of the body, and NF- $\kappa \mathrm{B}$ signaling dysfunction usually occurs during the pathogenesis of UC (Morinelli et al., 2013; Jeong et al., 2017). The NF- $\kappa B$ inhibitor- $\alpha$ $\mathrm{I} \kappa \mathrm{B}-\alpha$ represses NF- $\kappa \mathrm{B}$, which masks the nuclear localization signal of NF- $\kappa \mathrm{B}$, allowing NF- $\kappa \mathrm{B}$ to exist in cells as an inactive complex. The I $\kappa \mathrm{B}$ family includes $\mathrm{I} \kappa \mathrm{B}-\alpha$, $\mathrm{I} \kappa \mathrm{B}-\beta, \mathrm{I} \kappa \mathrm{B}-\gamma, \mathrm{I} \kappa \mathrm{B}-\delta, \mathrm{I} \kappa \mathrm{B}-\varepsilon$, and Bcl-3. Studies have shown that almost all NF- $\kappa \mathrm{B}$ inducers rapidly activate $\mathrm{NF}-\kappa \mathrm{B}$ through the degradation of I $\kappa \mathrm{B}-\alpha$. Therefore, activation of NF- $\kappa \mathrm{B}$ can be prevented by inhibiting the phosphorylation of I $\kappa \mathrm{B}-\alpha$ (Zhu et al., 2017; Liu et al., 2018). Probiotics can regulate the intestinal bacterial community, change the intestinal lumen, optimize the intestinal inflammatory environment, and ultimately improve intestinal barrier integrity and downregulate the expression of NF- $\kappa \mathrm{B}$ and other pro-inflammatory cytokines (Kanmani and Kim, 2018). In this study, the DSS-induced mice colitis model upregulated mRNA 
and protein expression of NF- $\kappa \mathrm{Bp} 65$ in the colon and downregulated the expression of $\mathrm{I} \kappa \mathrm{B}-\alpha$, suggesting that DSS-induced colitis may promote phosphorylation of I $\kappa \mathrm{B}-\alpha$ and activate the NF- $\kappa \mathrm{B}$ signaling pathway. We found that expression of NF- $\kappa \mathrm{Bp} 65 \mathrm{mRNA}$ and protein in the colon tissues of mice was decreased after L. fermentum CQPC04 was administered to mice with colitis but expression of I $\kappa \mathrm{B}-\alpha$ increased. These results indicate that this strain can reduce the phosphorylation of I $\kappa \mathrm{B}-\alpha$, thereby preventing the activation of the $\mathrm{NF}-\kappa \mathrm{B}$ signaling pathway, and ultimately reducing the release of other pro-inflammatory cytokines caused by $\mathrm{NF}-\kappa \mathrm{B}$ activation.

In addition to the discovery that $L$. fermentum CQPC04 inhibits the NF- $\kappa \mathrm{B}$ signaling pathway in the colon of colitic mice, we found that L. fermentum CQPC04 reduced the release and expression of

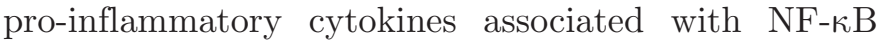
activation, and increased the release and expression of anti-inflammatory cytokines. Activation of NF- $\kappa \mathrm{B}$ in the intestinal mucosa further induces the release of cytokines and adhesion factors, which in turn stimulate
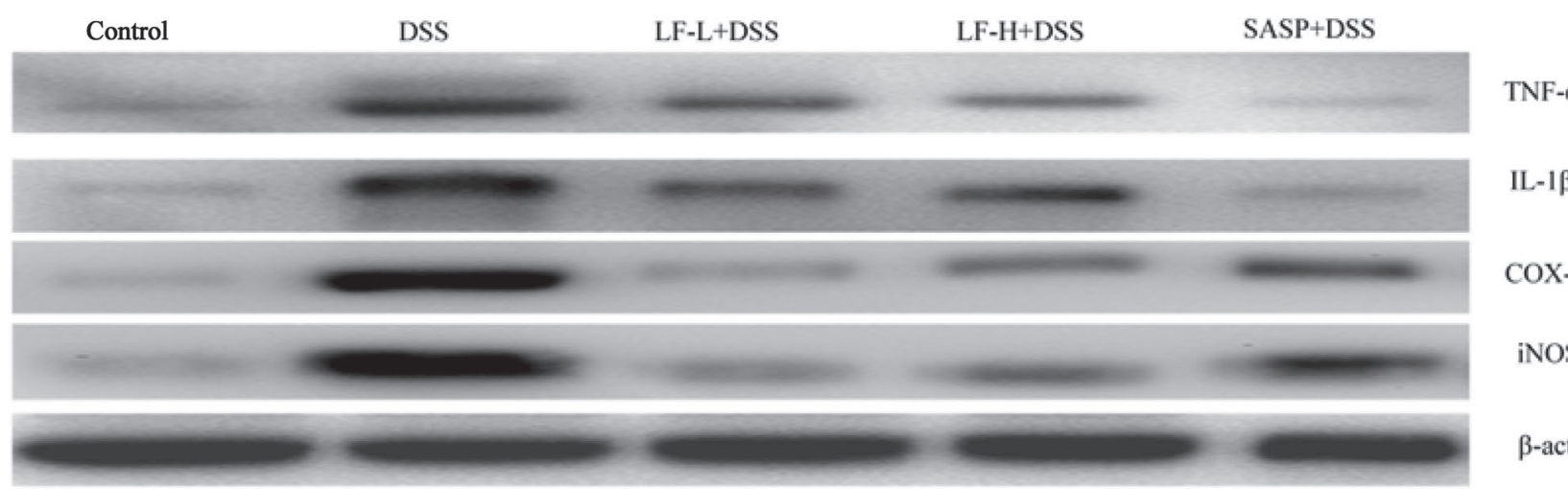

IL-1 $\beta$

COX-2

iNOS

$\beta$-actin
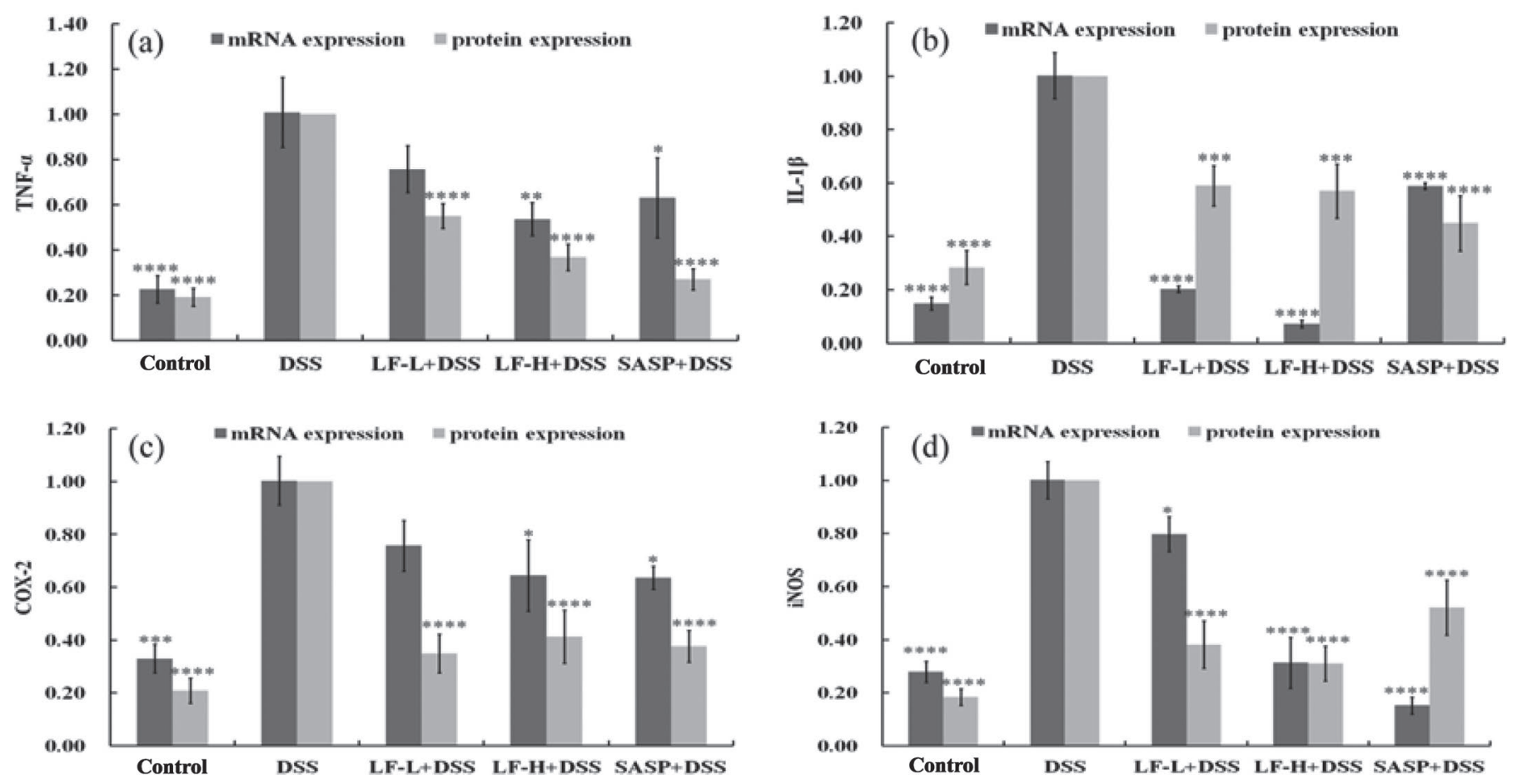

Figure 8. The mRNA and protein expression levels of tumor necrosis factor (TNF)- $\alpha$, IL-1 $\beta$, cyclooxygenase (COX)-2, and inducible nitric oxide synthase (iNOS) in colons of mice, expressed as fold change relative to DSS. Control = oral gavage with saline; DSS $=5 \%$ dextran sulfate sodium; LF-L+DSS = Lactobacillus fermentum CQPC04 $\left(1.5 \times 10^{9} \mathrm{cfu} / \mathrm{kg}\right.$ of BW $)$ plus $5 \%$ DSS; LF-H + DSS $=$ L. fermentum CQPC04 $(1.0 \times$ $10^{10} \mathrm{cfu} / \mathrm{kg}$ of BW) plus $5 \%$ DSS; SASP + DSS $=$ salicylazosulfapyridine $(500 \mathrm{mg} / \mathrm{kg}$ of BW) plus $5 \%$ DSS. Data are expressed as mean \pm SD; ${ }^{*} P<0.05,{ }^{* *} P<0.01,{ }^{* * *} P<0.001,{ }^{*} * * * P 0.0001$ compared with the DSS group. 
and activate NF- $\kappa \mathrm{B}$; for example, TNF- $\alpha$ can induce NF- $\kappa \mathrm{B}$ activation in different cell types (Kanda et al., 2017); TNF- $\alpha$ is a multifunctional cytokine involved in apoptosis, cell survival, inflammation, and immunity. Under the stimulation of TNF- $\alpha$, the body produces iNOS. This further catalyzes the production of high concentrations of cytotoxic nitric oxide (NO), which has toxic effects on cells. The mRNA expression of TNF- $\alpha$ and iNOS was significantly higher in UC patients than in the normal population (Rafa et al., 2017). Similar to TNF- $\alpha$, IFN- $\gamma$ is a typical macrophage-activating factor, and its increased secretion in individuals with colitis leads to local hypoxia in the intestinal mucosa, further promoting the synthesis of iNOS and thereby aggravating local inflammation (Qin et al., 2017). In the present study, we found that the levels of TNF- $\alpha$ and IFN- $\gamma$ in the serum of colitic mice were significantly increased, and their mRNA and protein expression in colon tissues also increased. When colitic mice were treated with $L$. fermentum CQPC04 by oral gavage, these indicators decreased significantly in serum, mRNA expression, and protein expression in colon tissues. These indicators were especially reduced in the $\mathrm{LF}+\mathrm{H}+\mathrm{DSS}$ group, indicating that L. fermentum CQPC04 regulates TNF- $\alpha$ and IFN- $\gamma$ expression in colitic mice, thereby reducing inflammatory damage.

Interleukin-1 $\beta$, IL-6, IL-12, COX-2, and iNOS are pro-inflammatory cytokines involved in the activation of NF- $\kappa \mathrm{B}$. Interleukin-1 is primarily secreted by neutrophils, endothelial cells, and mononuclear macrophages, and includes IL- $1 \alpha$ and IL-1 $\beta$, which are composed of 2 different gene polypeptides. Interleukin- $1 \beta$ is a proinflammatory factor that promotes the entry of inflammatory cells, such as neutrophils, into the intestinal
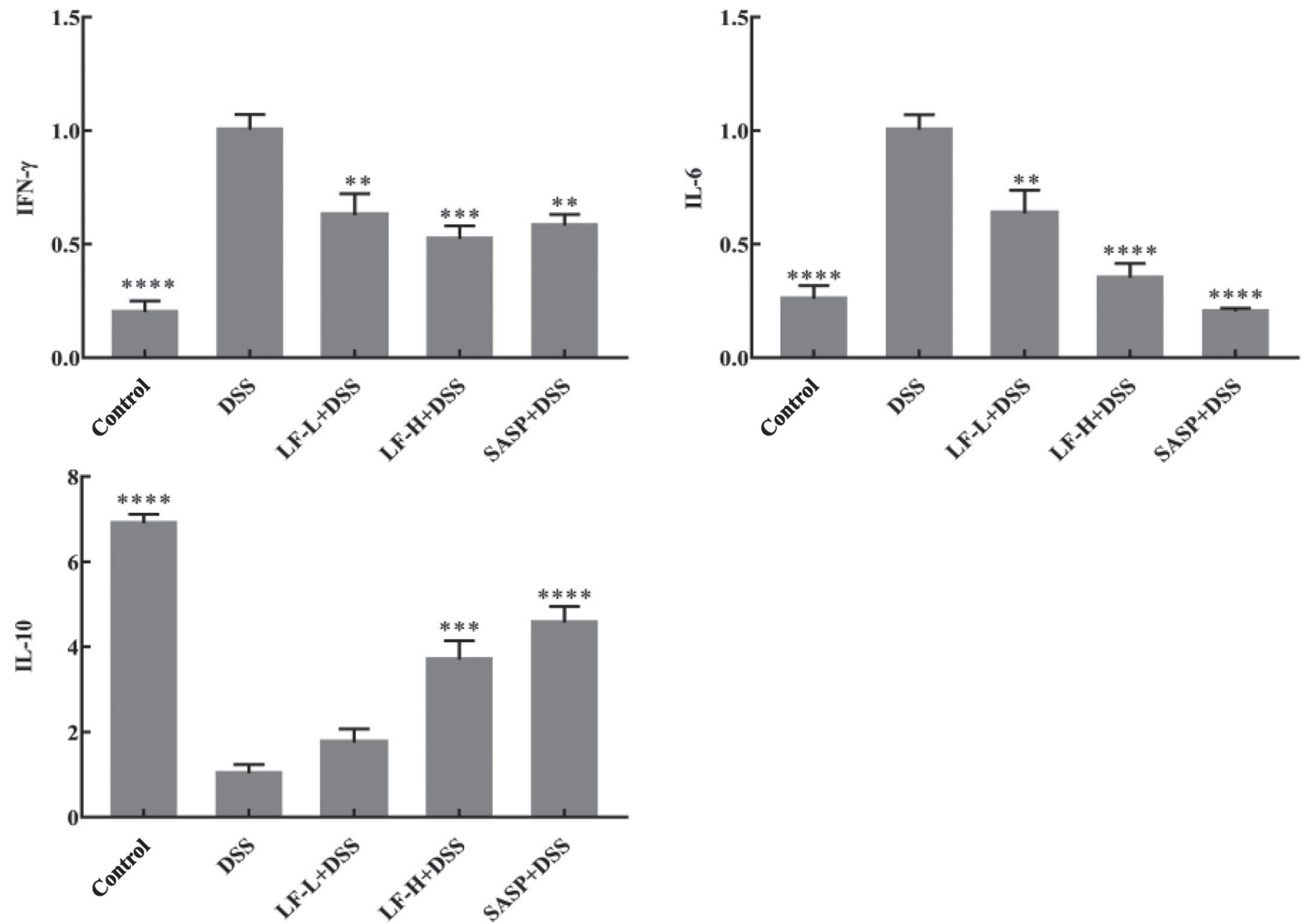

Figure 9. The mRNA expression of IFN- $\gamma$, IL-6, and IL-10 in colon, expressed as fold change relative to DSS. Control $=$ oral gavage with saline; DSS $=5 \%$ dextran sulfate sodium; LF-L+DSS = Lactobacillus fermentum CQPC04 $\left(1.5 \times 10^{9}\right.$ cfu $/ \mathrm{kg}$ of BW $)$ plus $5 \%$ DSS; LF-H+DSS $=$ L. fermentum CQPC04 $\left(1.0 \times 10^{10} \mathrm{cfu} / \mathrm{kg}\right.$ of BW) plus $5 \%$ DSS; SASP+DSS = salicylazosulfapyridine $(500 \mathrm{mg} / \mathrm{kg}$ of BW $)$ plus $5 \%$ DSS Data are expressed as mean $\pm \mathrm{SD} ;{ }^{*} P<0.01$, ${ }^{* * *} P<0.001$, ****P $<0.0001$ compared with the DSS group. 

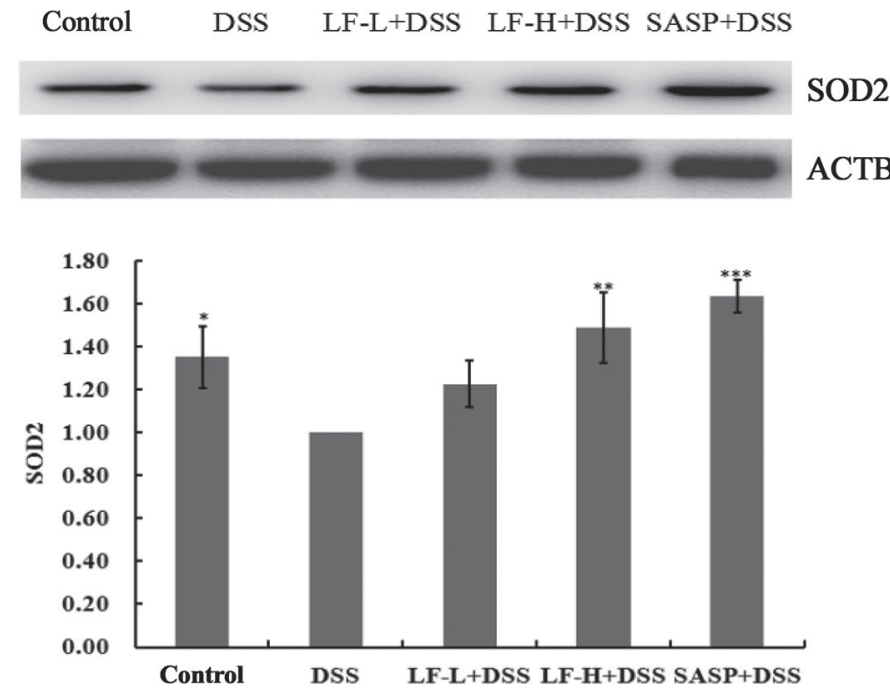

Figure 10. The protein expression of superoxide dismutase 2 (SOD2) in colons of mice, expressed as fold change relative to DSS. Control = oral gavage with saline; DSS $=5 \%$ dextran sulfate sodium; LF-L+DSS = Lactobacillus fermentum CQPC04 $\left(1.5 \times 10^{9} \mathrm{cfu} / \mathrm{kg}\right.$ of BW $)$ plus 5\% DSS; LF-H+DSS = L. fermentum CQPC04 $\left(1.0 \times 10^{10}\right.$ $\mathrm{cfu} / \mathrm{kg}$ of BW) plus $5 \%$ DSS; SASP+DSS = salicylazosulfapyridine $(500 \mathrm{mg} / \mathrm{kg}$ of BW) plus $5 \%$ DSS. Data are expressed as mean $\pm \mathrm{SD}$; ${ }^{*} P<0.05,{ }^{* *} P<0.01,{ }^{* * *} P<0.001$ compared with the DSS group.

tract by autocrine and paracrine modes, promotes the expression of vascular endothelial leukocyte adhesion molecules, and causes the destruction and inflammatory response of intestinal tissue (Lopetuso et al., 2013). Interleukin-6 is a biologically active, multidirectional, pro-inflammatory cytokine that acts similarly to IL-1 $\beta$; IL-6 can activate the NF- $\kappa \mathrm{B}$ signaling pathway to a certain extent, causing a chronic inflammatory response in the intestine. In addition, overexpression of IL-6 increases intestinal permeability, infiltrates inflammatory factors into the site of inflammation, and initiates inflammation (Lee et al., 2012). Studies have shown that the level of IL- 6 in the intestinal mucosa is much higher in individuals with UC than in healthy individuals, and its content decreases with remission of the disease (Schultz et al., 2017). Interleukin-12 is secreted by activated macrophages and dendritic cells. It has a strong pro-inflammatory effect and a synergistic effect with TNF- $\alpha$, IL-18, and IL-1 (Ryba-Stanisławowska et al., 2014). Cyclooxygenase (COX) is an important rate-limiting enzyme in the conversion of arachidonic acid into prostaglandins. It can be divided into 2 types, COX-1 and COX-2. The former is expressed constantly in normal tissues. Although it exhibits almost no expression in normal gastrointestinal mucosa, it displays increased expression in cancerous or inflammatory tissues, and studies have shown that COX-2 expression is elevated in experimental colitis ( $\mathrm{Li}$ et al., 2018b). Inducible ni- tric oxide synthase is not expressed in the normal state of the body but is overexpressed in the colonic mucosa of patients with inflammatory bowel disease. It can catalyze the production of $\mathrm{NO}$ and has toxic effects on arginine; excess NO increases the permeability of blood vessels and causes intestinal mucosal congestion and edema (Pavlick et al., 2002). Both iNOS and COX-2 are important inflammatory mediators, and excess NO can activate COX-2 via interaction at its active site, leading to increased inflammation (Suo et al., 2015). In this study, L. fermentum CQPC04 downregulated the expression of IL-1 $\beta$, IL-6, IL-12, COX-2, and iNOS at the serum, mRNA, and protein levels, thus reducing the inflammatory damage of inflammatory mediators in colitic mice, and exerting a preventative effect on the development of colitis.

Interleukin-10 is a potent anti-inflammatory cytokine secreted by macrophages, dendritic cells, and T cells. It plays an important role in maintaining the homeostasis of the intestinal tract and has a certain protective effect on intestinal epithelial cells (Keubler et al., 2015). It can reduce MPO activity, inhibit the activation of NF$\kappa \mathrm{B}$ in inflammatory cells, upregulate the IL-1RA/IL$1 \beta$ ratio, and inhibit other pro-inflammatory cytokines (such as TNF- $\alpha$, IL-1 $\beta$, and IFN- $\gamma$ ). Mice deficient in IL-10 or IL-10 receptors are more susceptible to colitis and are most similar to humans with inflammatory bowel disease (Hu et al., 2016). A study has shown that IL-10-deficient mice have more severe colonic symptoms after Clostridium difficile infection has aggravated colitis (Kim et al., 2014). Another study showed that the lentiviral vector-mediated local expression of IL-10 significantly increased the level of this cytokine while significantly reducing the levels of TNF- $\alpha$ and IFN- $\gamma$, and ultimately significantly reduced clinical manifestations of DSS-induced colitis in mice (Matsumoto et al., 2014). Based on the aforementioned studies, it is evident that IL-10 is important in the pathogenesis of colitis. In the present study, we found that levels of IL-10 in serum and tissues of mice with DSS-induced colitis decreased to varying degrees, but were increased in serum and colon tissues after the administration of $L$. fermentum CQPC04. The levels of IL-10 in the serum and tissues of the LF-H+DSS group were significantly higher than those in the DSS group, indicating that the experimental strain can regulate the expression of IL-10 in colitis mice and relieve the symptoms of inflammation in mice.

\section{CONCLUSIONS}

We isolated a new LAB, named Lactobacillus fermentum CQPC04, from traditional fermented pickles 
in Chongqing, China. The strain exhibited good in vitro resistance. By studying L. fermentum CQPC04 in DSS-induced colitis model mice, we found that it not only improved the disease symptoms of colitis mice at the macroscopic level (such as colon length and histopathological changes), but also at the serum, mRNA, and protein levels, by regulating the expression of antioxidant markers, pro-inflammatory cytokines, and anti-inflammatory cytokines. The strain could effectively alleviate the symptoms of colitic mice and could be used for the prevention and treatment of colitis. The mechanism by which L. fermentum CQPC04 improves the symptoms of DSS-induced colitis in mice could be related to the NF- $\kappa \mathrm{B}$ signaling pathway. However, studies on other signaling pathways are needed to determine the specific mechanism by which this strain improves symptoms of colitis. Other potential probiotic effects of L. fermentum CQPC04 on the human body need to be evaluated.

\section{ACKNOWLEDGMENTS}

This work was supported by the Foundation of Chongqing Science and Technology Bureau (grant numbers cstc2017shms-kjfp80011 and cstc2017shmskjfp80053); Venture and Innovation Support Program for Chongqing Overseas Returnees (project number: cx2018095); and the Fundamental Research Funds for the Central Universities (no. XDJK2017B039, Southwest University, China). The authors declare that they have no conflicts of interest.

\section{REFERENCES}

Aldini, R., M. Micucci, M. Cevenini, R. Fato, C. Bergamini, C. Nanni, M. Cont, C. Camborata, S. Spinozzi, M. Montagnani, G. Roda, A. D'Errico-Grigioni, F. Rosini, A. Roda, G. Mazzella, A. Chiarini, and R. Budriesi. 2014. Antiinflammatory effect of phytosterols in experimental murine colitis model: Prevention, induction, remission study. PLoS One 9:e108112.

Barko, P. C., M. A. McMichael, K. S. Swanson, and D. A. Williams. 2018. The gastrointestinal microbiome: A review. J. Vet. Intern. Med. 32:9-25.

Bohr, J., A. Wickbom, A. Hegedus, N. Nyhlin, E. Hultgren Hörnquist, and C. Tysk. 2014. Diagnosis and management of microscopic colitis: Current perspectives. Clin. Exp. Gastroenterol. 7:273-284.

Casas, A. I., V. T. Dao, A. Daiber, G. J. Maghzal, F. Di Lisa, N. Kaludercic, S. Leach, A. Cuadrado, V. Jaquet, T. Seredenina, K. H. Krause, M. G. López, R. Stocker, P. Ghezzi, and H. H. Schmidt. 2015. Reactive oxygen-related diseases: Therapeutic targets and emerging clinical indications. Antioxid. Redox Signal. 23:11711185.

Chassaing, B., J. D. Aitken, M. Malleshappa, and M. Vijay-Kumar. 2014. Dextran sulfate sodium (DSS)-induced colitis in mice. Curr. Protoc. Immunol. 104:Unit 15.25.

Chen, X., X. Zhao, H. Wang, Z. Yang, J. Li, and H. Suo. 2017. Prevent effects of Lactobacillus fermentum HY01 on dextran sulfate sodium-induced colitis in mice. Nutrients 9:545.
Currò, D., G. Ianiro, S. Pecere, S. Bibbò, and G. Cammarota. 2017. Probiotics, fibre and herbal medicinal products for functional and inflammatory bowel disorders. Br. J. Pharmacol. 174:1426-1449.

Di Meo, S., T. T. Reed, P. Venditti, and V. M. Victor. 2016. Role of ROS and RNS sources in physiological and pathological conditions. Oxid. Med. Cell. Longev. 2016:1245049.

Distrutti, E., L. Monaldi, P. Ricci, and S. Fiorucci. 2016. Gut microbiota role in irritable bowel syndrome: New therapeutic strategies. World J. Gastroenterol. 22:2219-2241.

Grover, S., H. M. Rashmi, A. K. Srivastava, and V. K. Batish. 2012. Probiotics for human health-New innovations and emerging trends. Gut Pathog. 4:15.

Hu, X., C. Han, J. Jin, K. Qin, H. Zhang, T. Li, N. Li, and X. Cao. 2016. Integrin CD11b attenuates colitis by strengthening Src-Akt pathway to polarize anti-inflammatory IL-10 expression. Sci. Rep. 6:26252.

Huang, Y., Y. Luo, Z. Zhai, H. Zhang, C. Yang, H. Tian, Z. Li, J. Feng, H. Liu, and Y. Hao. 2009. Characterization and application of an anti-Listeria bacteriocin produced by Pediococcus pentosaceus 05-10 isolated from Sichuan Pickle, a traditionally fermented vegetable product from China. Food Contr. 20. https://doi.org/10 $.1007 / \mathrm{s} 13213-015-1182-2$.

Jeong, H. Y., Y. S. Choi, J. K. Lee, B. J. Lee, W. K. Kim, and H. Kang. 2017. Anti-inflammatory activity of citric acid-treated wheat germ extract in lipopolysaccharide-stimulated macrophages. Nutrients 9:730.

Jiang, C., F. Zhao, J. Xiao, T. Zeng, J. Yu, X. Ma, H. Wu, and Y. Wu. 2013. Evaluation of the recombinant protein TpF1 of Treponema pallidum for serodiagnosis of syphilis. Clin. Vaccine Immunol. 20:1563-1568.

Kanda, Y., M. Osaki, and F. Okada. 2017. Chemopreventive strategies for inflammation-related carcinogenesis: Current status and future direction. Int. J. Mol. Sci. 18:867.

Kanmani, P., and H. Kim. 2018. Protective effects of lactic acid bacteria against TLR4 induced inflammatory response in hepatoma HepG2 cells through modulation of toll-like receptor negative regulators of mitogen-activated protein kinase and NF- $\kappa B$ signaling. Front. Immunol. 9:1537.

Keubler, L. M., M. Buettner, C. Häger, and A. Bleich. 2015. A multihit model: Colitis lessons from the interleukin-10-deficient mouse. Inflamm. Bowel Dis. 21:1967-1975.

Khan, I., and S. C. Kang. 2016. Probiotic potential of nutritionally improved Lactobacillus plantarum DGK-17 isolated from Kimchi-A traditional Korean fermented food. Food Control 60:88-94.

Kim, M. N., S. J. Koh, J. M. Kim, J. P. Im, H. C. Jung, and J. S. Kim. 2014. Clostridium difficile infection aggravates colitis in interleukin 10-deficient mice. World J. Gastroenterol. 20:17084-17091.

Kim, Y. E., M. Lee, H. Gu, J. Kim, S. Jeong, S. Yeo, Y. J. Lee, S. H. Im, Y. C. Sung, H. J. Kim, I. L. Weissman, and G. O. Ahn. 2018. HIF-1 $\alpha$ activation in myeloid cells accelerates dextran sodium sulfate-induced colitis progression in mice. Dis. Model. Mech. 11:dmm033241.

Kumar, B. V., S. Venkata, N. Vijayendra, O. Vijaya, and S. Reddy. 2015. Trends in dairy and non-dairy probiotic products - A review. J. Food Sci. Technol. 52:6112-6124.

Lee, H., H. Yoon, Y. Ji, H. Kim, H. Park, J. Lee, H. Shin, and W. Holzapfel. 2011. Functional properties of Lactobacillus strains isolated from kimchi. Int. J. Food Microbiol. 145:155-161.

Lee, M. J., J. K. Lee, J. W. Choi, C. S. Lee, J. H. Sim, C. H. Cho, K. H. Lee, I. H. Cho, M. H. Chung, H. R. Kim, and S. K. Ye. 2012. Interleukin-6 induces S100A9 expression in colonic epithelial cells through STAT3 activation in experimental ulcerative colitis. PLoS One 7:e38801.

Li, C., Y. Ma, Z. Mi, R. Huo, T. Zhou, H. Hai, L. Y. Kwok, Z. Sun, Y. Chen, and H. Zhang. 2018a. Screening for Lactobacillus plantarum strains that possess organophosphorus pesticide-degrading activity and metabolomic analysis of phorate degradation. Front. Microbiol. 9:2048.

Li, C., S. P. Nie, Q. Ding, K. X. Zhu, Z. Wang, T. X. J. Gong, and M. Y. Xie. 2014. Cholesterol-lowering effect of Lactobacillus plan- 
tarum NCU116 in a hyperlipidaemic rat model. J. Funct. Foods 8:340-347.

Li, Y., C. Soendergaard, F. H. Bergenheim, D. M. Aronoff, G. Milne, L. B. Riis, J. B. Seidelin, K. B. Jensen, and O. H. Nielsen. 2018b. COX-2-PGE2 signaling impairs intestinal epithelial regeneration and associates with TNF inhibitor responsiveness in ulcerative colitis. EBioMedicine 36:497-507.

Lin, L., and J. Zhang. 2017. Role of intestinal microbiota and metabolites on gut homeostasis and human diseases. BMC Immunol. 18:2.

Liu, B., S. Li, X. Sui, L. Guo, X. Liu, H. Li, L. Gao, S. Cai, Y. Li, T. Wang, and X. Piao. 2018. Root extract of Polygonum cuspidatum Siebold \& Zucc, ameliorates DSS-induced ulcerative colitis by affecting NF-kappaB signaling pathway in a mouse model via synergistic effects of polydatin, resveratrol, and emodin. Front. Pharmacol. 9:347.

Lopetuso, L. R., S. Chowdhry, and T. T. Pizarro. 2013. Opposing functions of classic and novel IL-1 family members in gut health and disease. Front. Immunol. 4:181.

Macotpet, A., F. Suksawat, P. Sukon, K. Pimpakdee, E. Pattarapanwichien, R. Tangrassameeprasert, and P. Boonsiri. 2013. Oxidative stress in cancer-bearing dogs assessed by measuring serum malondialdehyde. BMC Vet. Res. 9:101.

Matsumoto, H., K. Haga, I. Ohno, K. Hiraoka, T. Kimura, K. Hermann, N. Kasahara, P. Anton, and I. McGowan. 2014. Mucosal gene therapy using a pseudotyped lentivirus vector encoding murine interleukin-10 (mIL-10) suppresses the development and relapse of experimental murine colitis. BMC Gastroenterol. 14:68.

Matuszyk, A., P. Ceranowicz, Z. Warzecha, J. Cieszkowski, D. Ceranowicz, K. Gałazka, J. Bonior, J. Jaworek, K. Bartuś, K. Gil, R. Olszanecki, and A. Dembiński. 2016. Exogenous ghrelin accelerates the healing of acetic acid-induced colitis in rats. Int. J. Mol. Sci. $17: 1455$.

Miyamoto, M., Y. Seto, D. H. Hao, T. Teshima, Y. B. Sun, T. Kabuki, L. B. Yao, and H. Nakajima. 2005. Lactobacillus harbinensis sp. nov. consisted of strains isolated from traditional fermented vegetables 'Suan cai' in Harbin, Northeastern China and Lactobacillus perolens DSM 12745. Syst. Appl. Microbiol. 28:688-694.

Morinelli, T. A., M. H. Lee, R. T. Kendall, L. M. Luttrell, L. P. Walker, and M. E. Ullian. 2013. Angiotensin II activates NF$\kappa \mathrm{B}$ through AT1A receptor recruitment of $\beta$-arrestin in cultured rat vascular smooth muscle cells. Am. J. Physiol. Cell Physiol. 304:C1176-C1186.

Naeem, M., J. Bae, M. A. Oshi, M. S. Kim, H. R. Moon, B. L. Lee, E. Im, Y. Jung, and J. W. Yoo. 2018. Colon-targeted delivery of cyclosporine A using dual-functional Eudragit ${ }^{\circledR}$ FS30D/PLGA nanoparticles ameliorates murine experimental colitis. Int. J. Nanomedicine 13:1225-1240.

Ohtsu, T., A. Takagi, N. Uemura, K. Inoue, H. Sekino, A. Kawashima, M. Uchida, and Y. Koga. 2017. The ameliorating effect of Lactobacillus gasseri OLL2716 on functional dyspepsia in Helicobacter pylori-uninfected individuals: A randomized controlled study. Digestion 96:92-102

Pavlick, K. P., F. S. Laroux, J. Fuseler, R. E. Wolf, L. Gray, J. Hoffman, and M. B. Grisham. 2002. Role of reactive metabolites of oxygen and nitrogen in inflammatory bowel disease. Free Radic. Biol. Med. 33:311-322.

Pereira, D. I., and G. R. Gibson. 2002. Cholesterol assimilation by lactic acid bacteria and bifidobacteria isolated from the human gut. Appl. Environ. Microbiol. 68:4689-4693.

Qian, Y., J. Zhang, X. Zhou, R. Yi, J. Mu, X. Long, Y. Pan, X. Zhao, and W. Liu. 2018. Lactobacillus plantarum CQPC11 isolated from Sichuan pickled cabbages antagonizes D-galactose-induced oxidation and aging in mice. Molecules 23:3026.

Qin, L., Z. Q. Yao, Q. Chang, Y. L. Zhao, N. N. Liu, X. S. Zhu, Q. Q. Liu, L. F. Wang, A. G. Yang, C. F. Gao, and J. T. Li. 2017. Swimming attenuates inflammation, oxidative stress, and apoptosis in a rat model of dextran sulfate sodium-induced chronic colitis. Oncotarget 8:7391-7404.
Rafa, H., S. Benkhelifa, S. AitYounes, H. Saoula, S. Belhadef, M. Belkhelfa, A. Boukercha, R. Toumi, I. Soufli, O. Moralès, Y. de Launoit, H. Mahfouf, M. Nakmouche, N. Delhem, and C. TouilBoukoffa. 2017. All-trans retinoic acid modulates TLR4/NF- $\kappa \mathrm{B}$ signaling pathway targeting $\mathrm{TNF}-\alpha$ and nitric oxide synthase 2 expression in colonic mucosa during ulcerative colitis and colitis associated cancer. Mediators Inflamm. 2017:7353252.

Ragul, K., I. Syiem, K. Sundar, and P. H. Shetty. 2017. Characterization of probiotic potential of Bacillus species isolated from a traditional brine pickle. J. Food Sci. Technol. 54:4473-4483.

Reid. G., and J. A. Hammond. 2005. Probiotics. Some evidence of their effectiveness. Can. Fam. Physician 51:1487-1493.

Ryba-Stanisławowska, M., K. Rybarczyk-Kapturska, M. Myśliwiec, and J. Myśliwska. 2014. Elevated levels of serum IL-12 and IL18 are associated with lower frequencies of CD4(+)CD25 (high) FOXP3 $(+)$ regulatory t cells in young patients with type 1 diabetes. Inflammation 37:1513-1520.

Sáez-Lara, M. J., C. Robles-Sanchez, F. J. Ruiz-Ojeda, J. Plaza-Diaz, and A. Gil. 2016. Effects of probiotics and synbiotics on obesity, insulin resistance syndrome, type 2 diabetes and non-alcoholic fatty liver disease: A review of human clinical trials. Int. J. Mol. Sci. 17:928.

Schultz, B. M., C. A. Paduro, G. A. Salazar, F. J. Salazar-Echegarai, V. P. Sebastián, C. A. Riedel, A. M. Kalergis, M. Alvarez-Lobos, and S. M. Bueno. 2017. A potential role of Salmonella infection in the onset of inflammatory bowel diseases. Front. Immunol. 8:191.

Storr, M. A. 2013. Microscopic colitis: Epidemiology, pathophysiology, diagnosis and current management-an update 2013. ISRN Gastroenterol. 2013:352718

Suo, H., X. Feng, K. Zhu, C. Wang, X. Zhao, and J. Kan. 2015. Shuidouchi (fermented soybean) fermented in different vessels attenuates $\mathrm{HCl} /$ ethanol-induced gastric mucosal injury. Molecules 20:19748-19763.

Suo, H., X. Zhao, Y. Qian, P. Sun, K. Zhu, J. Li, and B. Sun. 2016. Lactobacillus fermentum Suo attenuates $\mathrm{HCl}$ /ethanol induced gastric injury in mice through its antioxidant effects. Nutrients 8:155.

Thomas, S., J. Izard, E. Walsh, K. Batich, P. Chongsathidkiet, G. Clarke, D. A. Sela, A. J. Muller, J. M. Mullin, K. Albert, J. P. Gilligan, K. DiGuilio, R. Dilbarova, W. Alexander, and G. C. Prendergast. 2017. The host microbiome regulates and maintains human health: A primer and perspective for non-microbiologists. Cancer Res. 77:1783-1812.

Wang, C., H. M. Cui, T. H. Huang, T. K. Liu, X. L. Hou, and Y. Li. 2016a. Identification and validation of reference genes for RT-qP$\mathrm{CR}$ analysis in non-heading Chinese cabbage flowers. Front. Plant Sci. 7:811.

Wang, Z., S. Li, Y. Cao, X. Tian, R. Zeng, D. F. Liao, and D. Cao. 2016b. Oxidative stress and carbonyl lesions in ulcerative colitis and associated colorectal cancer. Oxid. Med. Cell. Longev. 2016:9875298

Xiao, J., S. Li, Y. Sui, Q. Wu, X. Li, B. Xie, M. Zhang, and Z. Sun. 2014. Lactobacillus casei-01 facilitates the ameliorative effects of proanthocyanidins extracted from lotus seedpod on learning and memory impairment in scopolamine-induced amnesia mice. PLoS One 9:e112773.

Zhao, X., H. Suo, Y. Qian, G. J. Li, Z. H. Liu, and J. Li. 2015. Therapeutic effects of Lactobacillus casei Qian treatment in activated carbon induced constipated mice. Mol. Med. Rep. 12:3191-3199.

Zhao, X., R. Yi, Y. Qian, and K. Y. Park. 2018. Lactobacillus plantarum YS-3 prevents activated carbon-induced constipation in mice. J. Med. Food 21:575-584.

Zhu, C., S. Zhang, C. Song, Y. Zhang, Q. Ling, P. R. Hoffmann, J. Li, T. Chen, W. Zheng, and Z. Huang. 2017. Selenium nanoparticles decorated with Ulva lactuca polysaccharide potentially attenuate colitis by inhibiting NF- $\kappa \mathrm{B}$ mediated hyper inflammation. J. Nanobiotechnology 15:20. 